\title{
A Relational Analysis of Willful Hermeneutical Ignorance in Canada's Settler-Colonial Context
}

\author{
by
}

\section{Syeda Karishma Bristy}

A thesis submitted to the Faculty of Graduate and Postdoctoral Affairs in partial fulfillment of the requirements for the degree of

Master of Arts

in

\author{
Philosophy
}

Carleton University

Ottawa, Ontario

(C)2021, Syeda Karishma Bristy 


\begin{abstract}
In this thesis, I expand and apply the work of Miranda Fricker, Gaile Pohlhaus, José Medina, and Christine Koggel to argue that willful hermeneutical ignorance is the most appropriate entry point for analyzing epistemic injustice between settlers and Indigenous people. I examine how early settler-colonial relationships of power and oppression have evolved to help sustain a form of epistemic injustice towards Indigenous communities in Canada. I investigate the colonial history, legal legacies, and myths that create the fundamental asymmetries of material and hermeneutical power. This background context highlights how this history impacts the respective racial/social/epistemic positionality of White settler society and racialized migrant communities. I argue that each group holds a performative and interactive role in silencing and marginalizing Indigenous knowers as equal and valid epistemic agents. Lastly, I incorporate the relational insights gained from my analysis to inform/propose counteractive measures to address epistemic injustice towards Indigenous communities in Canada.
\end{abstract}




\section{Acknowledgements}

First, I would like to sincerely thank my supervisor, Dr. Christine Koggel. Her continued guidance, encouragement, and patience with me from the very beginning of my master's degree has made the completion of this thesis possible. I am very grateful to have learned and worked with her.

I wish to give thanks to my family and friends for their love and support. I give particular thanks to my Mum and Dad for teaching me resilience and constantly pushing me to do my best, to Gloria with whom I have shared my ideas, struggles, and milestones, to Shivani for your support throughout my academic journey, and to Andrew for your care, patience, time, and encouragement.

I also wish to acknowledge and pay respect to the Algonquin Anishnaabeg people on whose unceded traditional territories I completed my research and writing. As the central themes of this thesis include the nature and implications of hermeneutical gaps in settlers' understanding of Indigenous people's voice, past, and general interpretive resources, I recognize that I am starting from a place that is complicit in the dismissal of Indigenous interpretive resources and local knowledge. As an immigrant on this land, this thesis has been one of the first steps to understand the power, privilege, complicity, and responsibility I hold as a settler on Turtle Island. 


\section{Table of Contents}

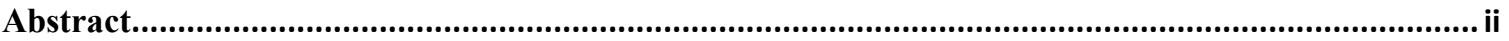

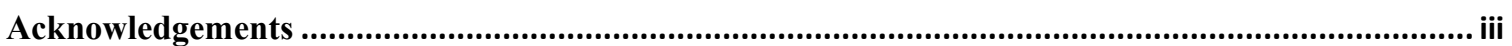

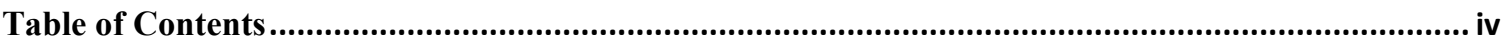

Chapter 1: Introduction ................................................................................................................... 1

Chapter 2: Willful Hermeneutical Ignorance ….......................................................................................5

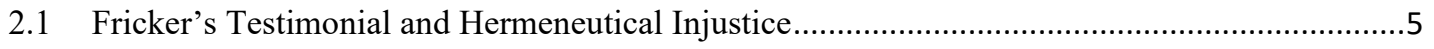

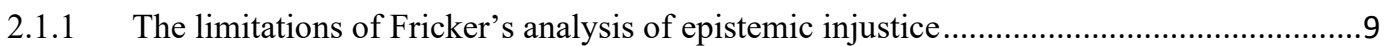

2.1.2 An expansion of Fricker's Hermeneutical Injustice by Pohlhaus .....................................12

2.1.2.1 Dialectical relations of situatedness and interdependence......................................13

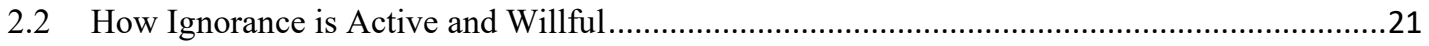

2.2.1 Pohlhaus's and Medina's central case: White Ignorance....................................................24

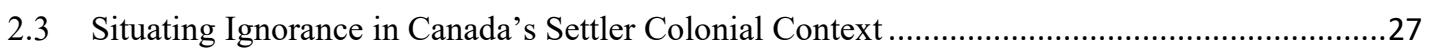

Chapter 3: Settler-colonialism as the Ontological Framework for Understanding Settler-Indigenous and Arrivant-Indigenous Relationships in Canada .................................................................................... 30

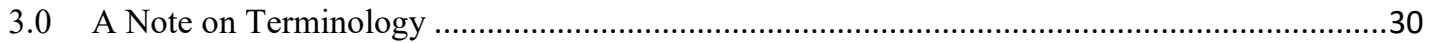

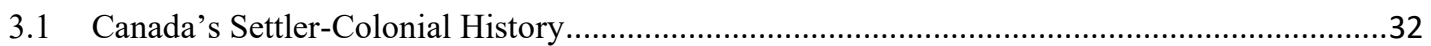

3.2 Displacing Indigenous People off their Land: Doctrine of Discovery and terra nullius ..............35

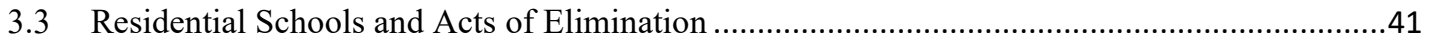

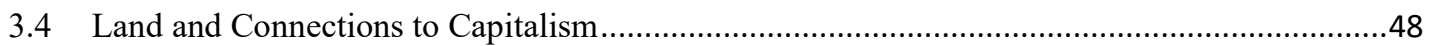

Chapter 4: Understanding the Relationships between Colonizer, the Colonized, and the Arrivant ... 54

4.1 How Myths Position White Settler Society as Hermeneutically Dominant: The Land, the

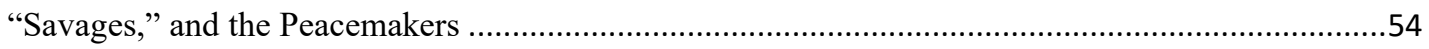

4.1.1 Myths of the benevolent peacemaker ……….........................................................56

4.2 The History and Social Positioning of Canada's Myths of Benevolence and Peacemaking ......61

4.2.1 Canada's leadership in international peacekeeping ……..............................................63

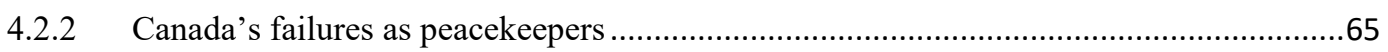

4.3 The role of Narrative and Myths in the Case of Arrivants ......................................................

Chapter 5: An Epistemology of Ignorance and Settler-Colonial Oppression in Canada ..................... 77

5.1 Denying Relationality and Willful White Ignorance...............................................................

5.2 Relational Aspects of Communicative Interactionism and Willful Hermeneutical Ignorance ...83

5.3 Pre-emptive Dismissal, Silencing and the Fragility of Communication.....................................

5.3.1 Systemic distortion and interpretive resources within Indigenous communities ..............91

5.4 Hermeneutical Responsibility and Creating New Interpretive tools .......................................93 
Chapter 6: Corrective Methodological Responses to Willful Hermeneutical Ignorance......................96

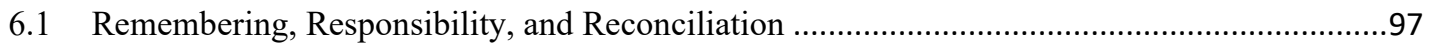

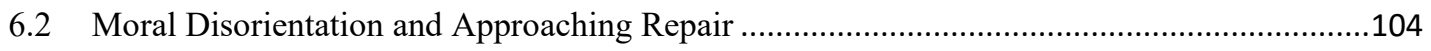

6.2.1 The experience and value of disorientation and White ambush in moral life ..................104

6.2.2 Applying lessons from moral disorientation: doubling back and settler-colonialism.....106

6.2.3 Moral deference and disorientation as a practice of methodological decentering for

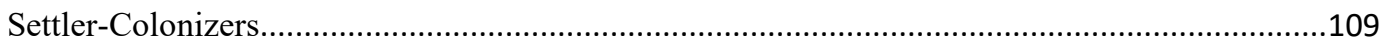

6.3 Resistance and Allyship in Arrivant Communities .............................................................112

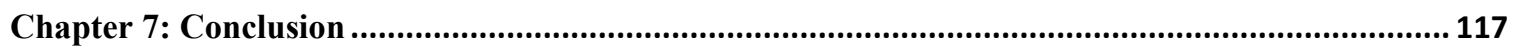

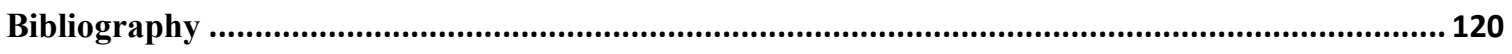




\section{Chapter 1: Introduction}

In her book Epistemic Injustice: Power and the Ethics of Knowing (2007), Miranda Fricker identifies two forms of epistemic injustice that explain the expressive and interpretative aspects of oppression/marginalization: testimonial and hermeneutical injustice. Testimonial injustice pertains to the way in which a hearer is biased against an interlocutor's credibility, and hermeneutical injustice occurs when the intelligibility of an interlocutor is unfairly constrained or undermined structurally: "when a gap in collective interpretive resources puts someone at an unfair advantage when it comes to making sense of their social experience" $(2007,1)$. In this thesis, I focus primarily on Fricker's characterization of hermeneutical injustice as a starting point to investigate the epistemic injustice that occurs in the colonial relationships that exist within the settler-colonial state now called Canada by looking at how settlers not only occupy the dominant hermeneutical space but also have disregarded and continue to disregard Indigenous interpretive resources.

In Chapter 2, I provide background on Fricker's conceptions of testimonial and hermeneutical injustice and focus on the limitations of her account. I draw on the work of her critics, Gaile Pohlhaus, José Medina, and Christine Koggel, each of whom has expanded her account by shifting their analysis to address the relational context of hermeneutical injustice. Each theorist examines how our positionality affects what we are likely to know and are willing to be ignorant about. In doing so, I highlight how marginally situated knowers are often not constrained in their intelligibility to themselves or others, but rather, are willfully dismissed as knowers in their relationships with dominantly situated knowers. Subsequently, I outline Pohlhaus's conception of willful 
hermeneutical ignorance, which describes "instances where marginally situated knowers actively resist epistemic domination through interaction with other resistant knowers while dominantly situated knowers continue to misunderstand and misinterpret the world" (Pohlhaus 2012, 716). Here, I draw from Pohlhaus's attention to relational features and to feminist relational theory more generally as a starting point to examine how power and oppression in settler-colonial histories and contexts influence a type of willful hermeneutical ignorance in Canada. I draw from Koggel's work, which critiques how Canada's dominant collective interpretive resources reflect "attempts to denigrate, dismiss, and erase Indigenous laws, practices, languages and traditions" as a way of situating the role of ignorance and the need for a relational analysis of settler-colonial power and oppression in understanding epistemic injustice in Canada (Koggel 2019, 1).

In Chapter 3, I cover the specific history and context of Canada as a settler/colonial nation. I look at how legal fictions like the Doctrine of Discovery and mythologies around it are still fundamentally centered on gaining sovereignty over Indigenous peoples, their lands, and resources through a structured dispossession of their land and resources. Moreover, I look at how residential schools and the people who supported them (such as politicians and the setter-colonial publics) participated in an attempted erasure of Indigenous beliefs, laws, languages, and traditions. In doing so, I highlight how a settler mindset has led to the ignoring and erasing of Indigenous peoples and their collective interpretive resources and has instead maintained a mindset that centers White settler societies' collective interpretive resources. In conjunction with covering this history, I show that despite erasure and marginalization, Indigenous collective interpretative resources have continued to survive in a way that demonstrates 
robust understandings of their experiences through resistance and by creating their own resources interdependently within their communities.

Chapter 4 discusses how the history and project of settler-colonialism covered in Chapter 2 play out nationally and globally in myths about 'Canadians' as benevolent peacemakers and peacekeepers. More specifically, I examine various myths regarding how White settlers perceive themselves in their interpretive resources domestically and internationally. These myths inform the dominant historical perception of Indigenous people and the colonization of their land; they also impact the interpretive resources that 'arrivants' - a term I use to describe racialized immigrants in the context of Canada as a settler-colonial nation — may take up. For arrivants, I demonstrate how these myths get passed on in efforts to assimilate arrivants both by arrivants themselves and by 'Canadians' at large to sustain a collective interpretive resource that positions White settler society as the norm.

In Chapter 5, I apply and extend Pohlhaus's and Medina's work on the topic of willful hermeneutical ignorance. I expand Medina's framework of communicative interactionism to better understand hermeneutical injustice and then apply this to the case and context of settler-Indigenous relations in Canada. First, I show that White settlerscolonizers have the power and privilege to willfully refuse and disqualify Indigenous knowers as equal and valid epistemic agents. Second, I build on Medina's insights to carry out an analysis of how settler-colonizers and arrivants have a performative and interactive role in and through the ways they silence and fail to listen to Indigenous peoples and how this failure may cause systemic distortions for some Indigenous peoples about settler-colonialism and its subsequent past and current harms to Indigenous 
communities. In doing so, I also consider the issue of responsibility with respect to hermeneutical injustice and argue for a collectively shared responsibility for settlers in Canada to be held responsible for their hermeneutical insensitivities and neglect.

In Chapter 6, I theorize on how best to approach correcting the interactive and performative aspects of willful hermeneutical ignorance entrenched in a settler-colonial history that has shaped networks of relationships of power. To do so, I draw on the work of Sue Campbell, Koggel, Ami Harbin, and Laurence Thomas to put together a methodological approach that I think can help highlight two things: 1) settlers' responsibility through the need to remember the past well and renew and rebuild relationships between Indigenous communities and settler populations, and 2) suggestions about how to challenge, change, and create new interpretative tools. Lastly, I look at the unique position of arrivants as marginalized knowers and how this position may provide them with an acute sensitivity to identifying hermeneutical gaps, which might help them resist the collective interpretive resources that have already been entrenched in and constituted by White settler society.

In Chapter 7, I conclude by reflecting on what has brought me to thinking about willful hermeneutical ignorance in Canada and providing a brief summary of my account of willful hermeneutical ignorance in Canada's settler colonial context. 


\section{Chapter 2: Willful Hermeneutical Ignorance}

In this chapter, I examine the concept of willful hermeneutical ignorance in order to lay the groundwork for engaging in the broader project of exploring how it functions as a deep-seated mode of oppression inflicted on Indigenous peoples by settler Canadians. I draw on the work of Miranda Fricker, Gaile Pohlhaus, and José Medina to outline the nature and implications of willful hermeneutical ignorance. In sections 2.1-2.2, I introduce Fricker's formulation of epistemic injustice and outline how it has been criticized, expanded, and applied by Pohlhaus and Medina, respectively. In sections 2.2 2.2.1, I outline how Pohlhaus and Medina develop their argument and treatments of willful ignorance by examining the issues of racially privileged, ignorant White subjects and White ignorance. In section 2.3, I situate the topic of epistemic injustice in the Canadian settler-colonial context. I do this so that in Chapter 3-5, I can establish how willful hermeneutical ignorance most appropriately captures the type of profound epistemic injustice present between Indigenous and non-Indigenous peoples in the settler colonial context of 'Canada.'

\subsection{Fricker's Testimonial and Hermeneutical Injustice}

In Epistemic Injustice: Power and the Ethics of Knowing (2007), Miranda Fricker identifies two forms of epistemic injustices, testimonial and hermeneutical, that are inflicted upon someone in their capacity as a knower. Fricker develops her account of testimonial and hermeneutical injustices with the following definitions.

Testimonial Injustice occurs primarily when a hearer has an identity prejudice towards the interlocutor that leads the hearer to withhold recognition of the interlocutor as a knower (Fricker 2007, 4). Alternatively, Hermeneutical Injustice is defined as "the 
injustice of having some significant area of one's social experience obscured from collective understanding owing to a structural identity prejudice in the collective hermeneutical resource" (Fricker 2007, 155).

A good example I consider as testimonial injustice throughout this chapter is the case of White medical practitioners who do not believe a woman of color's testimony of the pain she feels during a medical examination. Here, testimonial injustice might occur because of a doctor's social and identity power that allows him to dismiss her concerns based on an identity prejudice against women of color. Fricker states, "Whenever there is an operation of power that depends in some significant degree upon such shared imaginative conceptions of social identity, then identity power is at work" (14, my emphasis). Identity power often works in conjunction with social power, which Fricker defines as "a capacity we have as social agents to influence how things go in the social world" (9). We see that the doctor has social and identity power (by way of his social position in the context of broader historical and contemporary social and economic privilege as a White, educated man) that gives him the capacity to potentially dismiss and silence his patient's testimony of pain either actively or passively by evoking an existing social conception of women as less intelligent and/or a person of colour (hereafter referred to as POC) as less prone to feeling pain. Studies show that White (and nonWhite) medical practitioners not only have implicit identity prejudice against people of colour, but also towards people who have multiple minority identities (Chapman, Kaatz, and Cranes 2013; U.S. Institute of Medicine 2003). For example, a White male doctor may see a Black woman through prejudicial labels that deem her social group as exaggerators, less intelligent, or less prone to feeling pain and take these prejudices to be 
valid reasons to dismiss or disregard her medical testimonies (implicitly or explicitly). Accordingly, we can understand the doctor's dismissal of his patient's pain because of some existing perceptions of her social identity resulting in an identity prejudice held by the doctor. In this way, the central case of testimonial injustice is characterized by speakers receiving deflated credibility due to an identity prejudice held by the listener towards the speaker (Fricker 2007, 4). Note that although the central case of testimonial injustice for Fricker occurs between individuals, it can also manifest structurally via racist treatments embedded in the medical tools one uses to understand the experiences of someone else.

Spirometers as tools for measuring lung performance are a good example for capturing the racism underlying medical treatment. Recent studies show that this device has a 'race correction' feature that has values measuring lung health reduced $10-15 \%$ for Black people and 4-6\% for Asian people (Braun 2015). This practice was introduced in pulmonology through a legacy of racist practices and beliefs by physicians who wanted to 'show' that enslaved African Americans had weaker lungs than White Americans as a "marker of difference" and as justification for the prescription of forced labor as a remedy (Orenstein 2013). A consequence of this racist legacy in the medical field is that it works to discredit present-day testimonies by Black and Asian patients involved in compensation cases for occupational lung disease. In this case, the same tool used to measure their lung performance requires them to display greater lung damage than their White counterparts. The examples I have outlined so far demonstrate how testimonial injustice can be inflicted on POCs in medicine, whether intentionally or not, by health care practitioners or systemically by standardized racist medical treatments. 
According to Fricker, unlike testimonial injustice, hermeneutical injustice is experienced by those who are hermeneutically marginalized (also referred to as a 'marginally situated knower'). ${ }^{1}$ Fricker defines hermeneutical marginalization as instances in which the historical exclusion or oppression of a certain group causes their unequal participation in practices through which "social meanings are generated" (Fricker 2007, 6). This type of marginalization causes the social experiences of certain groups to be "left inadequately conceptualized" and thus, left out of the collective interpretative resources (Fricker 2007, 6). The central case in Fricker's discussion of hermeneutical injustice is exemplified by women's experiences of sexual harassment before the concept of sexual harassment was collectively understood in society (6). To expound this case, she references and examines the experience of Carmita Wood, an administrative assistant at Cornell University. Wood was targeted by nuclear physicist Boyce McDaniel, who would make inappropriate gestures towards her and touch her without consent in opportune settings (i.e., cornering her in an elevator to kiss her) (Fricker 2007, 150). Although Wood did what she could to avoid unnecessary encounters with McDaniel, the stress of experiencing sexual harassment physically manifested as neck and back pain (150). When all attempts to avoid McDaniel failed, Wood quit her job and applied for unemployment insurance. According to Fricker's account, when a claim investigator questioned why she had quit her job, Wood was unable to understand her experience of 'sexual harassment' and claimed that it was for personal reasons. Her claim for unemployment benefits was subsequently denied (150).

\footnotetext{
${ }^{1}$ Note that the hermeneutical marginalization creates a class of sub-knowers in society which other philosophers, such Gaile Pohlhaus, also refer to as "marginally situated knowers." I will be using these terms interchangeably.
} 
For Fricker, this case demonstrates how collective hermeneutical/interpretative resources can have hermeneutical gaps where "the name of a distinct social experience" (in this case, sexual harassment) should be (150). In this case, she regards both the harasser and the harassed as "cognitively handicapped" due to their lack of understanding regarding the true nature of the harasser's actions (even if the situation serves the harasser's agenda) (151). Such a cognitive handicap prevents women like Carmita Wood from understanding an important part of their experience and prevents her assailant, Boyce McDaniel, from properly understanding the seriousness of his crime. Thus, this case reveals three important characteristics of hermeneutical injustice on Fricker's account: 1) hermeneutical injustice is structural, 2) the individuals who face this injustice cannot comprehend their own experiences properly, and 3) they cannot render it "communicatively intelligible to others" and are, thus, unable to bring it forward as a collective hermeneutical/interpretive resource (Fricker 2007, 6; my emphasis). In the following section, I outline the limitations of these three characteristics as ones that have been examined and expanded upon by Fricker's critics. Features of Fricker's account of hermeneutical injustice will be revisited in section 2.2 to locate an important oversight by Fricker.

\subsubsection{The limitations of Fricker's analysis of epistemic injustice}

Fricker's characterization of hermeneutical injustice centers the experiences of the marginally situated knower in terms of intelligibility in two ways: intelligible to oneself and intelligible to others. Pohlhaus and Medina argue that this is not always the case. Both scholars specify that through developing new interpretive resources, marginalized 
knowers ${ }^{2}$ can achieve robust understandings of their experiences even while their experiences remain misunderstood and/or obscured from the hermeneutically dominant and powerful (Pohlhaus 2012, 719; Medina 2012, 207). The social experience of a marginally situated knower may be obscured from the collective understanding, but it is not necessarily obscure to the marginally situated knower or to her marginally situated community. They argue that, more often than not, communities of marginally situated knowers can not only comprehend their experiences, but they also freely discuss such experiences within their own communities and routinely make apparent their conceptual resources via resisting dominantly situated knowers' monopoly on collective hermeneutical resources.

Returning to Fricker's example, hermeneutical gaps, such as the one that Carmita Wood was subjected to, may render her experience unintelligible to dominantly situated knowers, but I emphasize that this does not mean it was entirely unintelligible to her. Wood's story shows us exactly how she understood her experiences through a counterinterpretation of the dominant understanding of sexual harassment (as 'harmless flirting' or 'fun'). In fact, Wood resisted harassment by Boyce McDaniel, resigned from her employment at Cornell University, and eventually pursued a lawsuit after working with other women to name and thereby coin the phenomenon as 'sexual harassment.' Wood's effort to help identify 'sexual harassment' in the workplace demonstrates a powerful resistance to the notions of 'overreacting to harmless flirting' as well as a sensitivity by marginalized knowers to the gaps in the interpretive resources of dominantly situated knowers. Furthermore, this part of her story affirms Medina's claim that, through

\footnotetext{
${ }^{2}$ I will be using the term marginally situated knower and marginalized knower interchangeability.
} 
working with each other and developing new interpretive resources, marginally situated knowers can achieve robust understandings of their experiences even while their experiences remain misunderstood and/or obscured from the hermeneutically dominant and powerful (Medina 2012, 207-209). The main message here is that hermeneutical injustice can also be caused by relevant factors that maintain dominant interpretations and systemically misrepresent the experiences of marginally situated knowers.

Accordingly, Fricker's analysis of hermeneutical injustice does not bring into focus how marginally situated knowers can resist epistemic domination, be sensitive to dominant hermeneutical interpretive resources, and produce counter-interpretations of their experiences. I highlight that Wood must have had some understanding of her own experiences of sexual harassment as not 'harmless flirting' because 1) she resisted the harassment in multiple ways on the feeling that it was wrong, unwanted and harmful; 2) she resigned from her job to prevent the harm it was having on her; and 3) she was sufficiently in tune with her experience to pursue a lawsuit against the insurance company while working with, and being represented by, other women who related to her experiences. Although Wood ultimately lost her case, her lawsuit became the catalyst to coining the term and to the acceptance of sexual harassment in court proceedings. Naming sexual harassment later became a key step for African American women, like Anita Hill, in their fight to make sexual harassment illegal (Brownmiller and Alexander, 1992).

Before proceeding, I would like to note that this is not an exhaustive list of Fricker's critics and the evolving notion of epistemic injustice. My primary focus in this chapter is to expound on how positionality and relationality are crucial in the instigating 
and sustaining of hermeneutical injustice caused by willful ignorance. As such, I draw primarily from Pohlhaus and Medina in the following sections of this chapter as they shift Fricker's original accounts of hermeneutical/epistemic injustice to consider how social relations may instantiate active and willful ignorance.

\subsubsection{An expansion of Fricker's Hermeneutical Injustice by Pohlhaus}

In "Relational Knowing and Epistemic Injustice: Toward a Theory of Willful Hermeneutical Ignorance" (2012), Pohlhaus further addresses the limitations of Fricker's account of hermeneutical injustice by criticizing how Fricker defines and distinguishes testimonial and hermeneutical injustice. Pohlhaus notes that sometimes communities of marginally situated knowers ${ }^{3}$ have ample conceptual resources, but dominantly situated knowers ${ }^{4}$ often willfully dismiss this fact. Pohlhaus calls this willful hermeneutical ignorance, defining it as the "refusal to acknowledge already developed epistemic resources for knowing the world from situations other than one's own" (Pohlhaus 2012, 733; emphasis added). While Fricker's analysis of hermeneutical injustice focuses on how hermeneutically marginalized individuals fail "to understand their own experiences" (Fricker 2007, 147-148), Pohlhaus's analysis shifts to the relational context of hermeneutical injustice to analyze how social relations affect "what we are likely to know" and what we are willing to know (717). This argument relies on her account of dialectical relationships emerging from situatedness and interdependence. While Fricker is aware of the significance of social power, she is less aware of how power is created and shaped in social relations and what this means for what knowers can know.

\footnotetext{
${ }^{3}$ Here, marginally situated knowers would be referred to as the 'hermeneutically marginalized' or 'hermeneutically disadvantaged' in Fricker's terminology.

${ }^{4}$ Fricker would also refer to dominantly situated knows as 'the hermeneutically powerful'.
} 


\subsubsection{Dialectical relations of situatedness and interdependence}

Pohlhaus defines situatedness as "situations in which the knower finds herself repeatedly over time due to the social relations that position her in the world" (Pohlhaus 2011, 717). A central insight of feminist standpoint theory and feminist epistemology, more generally, is that such situatedness or social positioning of a person influences the context from which one approaches the world and understands their lived experiences. Moreover, Pohlhaus explains that marginally situated knowers must grasp the epistemic/conceptual resources of the dominantly situated to "[know] those parts of the world toward which their situatedness orients them" (Pohlhaus 2012, 717). Marginalized knowers are socially vulnerable to the dominantly situated, which requires the marginalized to be more aware of the expectations, sensibilities, and concerns of the dominantly situated. According to Pohlhaus, however, the reverse is not true (717). In either case, the situatedness of the marginalized knower, in relation to the dominant to whom she is vulnerable, reveals how important social relations are to being able to understand how marginalized groups know and experience the world (717). At the same time as Pohlhaus shows the relationship of dependence of the marginally situated to those who are dominant, her other key point is that all knowers are interdependent with others. Consequently, the epistemic resources that we use to understand the world around us, such as language and concepts, are created, shaped, and given meaning communally. She states, in order to know the world in which she is situated, the knower needs to make sense of her experiences via interdependently held epistemic resources; she cannot just hold true beliefs about the world without being 
able to demonstrate that they are true, let alone without being able to formulate the beliefs themselves.

(Pohlhaus 2012, 719)

In other words, individuals cannot create, maintain, or preserve epistemic resources in isolation. My situatedness influences what I know, but my interdependence with others often determines what epistemic resources I come to know or whether I know of them at all. Pohlhaus calls this a 'dialectical relationship' between these two ways of knowing (716-722). Accordingly, when there is a "tension" between our situated experiences of the world and the interdependently determined ways in which we make sense of our experiences, hermeneutical gaps arise (716). In response to such gaps, we are meant to "recalibrate our epistemic resources and/or create new ones until the tension between our resources and the experienced world is alleviated" (719). However, Pohlhaus recognizes that not everyone is equally socially positioned to have influence over the recalibration of epistemic resources. It is here that Fricker's account of social power has force, though Pohlhaus takes her account of social positioning further than does Fricker by building in the relevance of relationships themselves. Pohlhaus argues that the dialectical relationship between situatedness and interdependence compounded with the power dynamic between marginalized and dominantly situated knowers can also lead to a distinct form of epistemic injustice that Fricker overlooks. Pohlhaus's arguments can be summarized in the following way.

P1. Marginalized knowers are vulnerable to the dominantly situated in ways that often require them to be more aware of the dominantly situated group's sensibilities, concerns, and experiences of the world (719). 
P2. The marginalized knower uses the epistemic resources that make sense of the dominantly situated groups' experiences, but this is not true the other way around (717).

P3. Marginally situated knowers are likely to find gaps in the collective/dominant epistemic resources for making sense of their experiences (717).

P4. This asymmetrical way of knowing each other's worlds and experiences between marginally and dominantly situated knowers creates a collectively recognized epistemic resource that makes more sense of "that which arises from the experienced world of the dominantly situated than that which arises from the experienced world of the marginally situated" (719).

P5. As such, marginalized knowers are better positioned to use and be aware of dominant/collective epistemic resources. They are also better positioned to notice hermeneutical gaps where there should be resources that represent the experienced world of the marginally situated (716-719).

P1 to P2 might indicate that being marginally situated is epistemically disadvantageous (or "cognitively handicapped," as Fricker would call it); however, Pohlhaus argues otherwise. Insights central to feminist standpoint theory allow Pohlhaus to argue that, given the dialectical relationship between situatedness and interdependence, only the hermeneutically marginalized can notice the inadequacy of the collective epistemic resources that fail to make sense of the parts of the world that the dominantly situated do not experience. Moreover, due to their vulnerability in a stratified society, marginally situated knowers also have the advantage of being aware of the epistemic resources of the dominant and collective. In this way, Pohlhaus argues through P4 and P5 
that "the epistemic resources developed from marginalized situatedness will be suited to more of the experienced world in general" (721). By analyzing the relation between a knower's situatedness and interdependence, Pohlhaus recognizes that the marginally situated (or hermeneutically marginalized as per Fricker) have epistemic advantages regardless of whether they are intelligible to the dominantly situated. This leads Pohlhaus to P6 which concludes that "Distinguishing between situatedness and interdependence thus allows us to maintain that marginalized situatedness is epistemically advantageous while also holding those dominantly situated responsible for not knowing the experienced world of those marginally situated" (Pohlhaus 2012, 721).

Individuals and groups who are marginally situated know that there are large parts of the world that dominantly situated knowers are just not epistemically equipped to understand (729). As such, Pohlhaus argues that it is at least possible for the dominantly situated to come to know such parts of the world. This idea is another crucial point of departure and expansion for Pohlhaus in her analysis of Fricker's framework of epistemic injustice. In Fricker's account, hermeneutical injustice occurs for those who are marginally situated due to some significant area of their experiences being obscured from collective understanding. For her, the reason their experiences are obscured or unintelligible to themselves and others is that they have been excluded from meaningmaking practices in society that could name their experiences. However, in her analysis of the dialectical relation between situatedness and interdependence (P3 and P4), Pohlhaus reveals two important characteristics of marginalized knowers in society. First, marginalized knowers know more parts of the world because of their attunement to the dominant's epistemic resources; and second, they are also privy to their otherwise 
socially obscured experiences via the epistemic resources they develop with other marginally situated knowers. Note that this reflects what Carmita Wood 'knew' before the term sexual harassment was created by her colleagues and legal representatives.

Though I will return to this point later in Chapters 4 and 5, it will be an important part of my account to argue that despite challenges, such as not sharing the same experiences or not gaining the trust of the marginally situated, dominantly situated knowers can, and sometimes do, learn to have a more objective, less partial perspective of the world when they learn to use and understand the epistemic resources of the marginally situated. For now, however, the point is that dominantly situated knowers may preemptively dismiss aspects of the world outside their experiences as unimportant. Pohlhaus explains that "we also see this happen when those situated dominantly dismiss the viability of such arduously honed concepts like "White privilege," "date rape," or "hetero normativity" (722). As such, Pohlhaus notes that, even when communities of marginally situated knowers have ample conceptual resources, dominantly situated knowers often willfully dismiss this knowledge. Pohlhaus calls this action willful hermeneutical ignorance. Willful hermeneutical ignorance describes "instances where marginally situated knowers actively resist epistemic domination through interaction with other resistant knowers while dominantly situated knowers continue to misunderstand and misinterpret the world" (716).

Pohlhaus argues that those who are dominantly situated are incentivized to "maintain ... their experiences of the world as generalizable to the entirety of reality, a close-mindedness to the possibility that others may experience the world in ways they cannot" (Pohlhaus 2017, 17). Here, Pohlhaus also departs from Fricker's account of how 
hermeneutical injustice can be addressed or alleviated. Fricker's account suggests that once the marginalized knower's experiences become intelligible to her through adequate epistemic resources, hermeneutical injustice ceases. Pohlhaus's willful hermeneutical ignorance shows that, regardless of the intelligibility of the marginalized knower's experiences, many will continue to preemptively dismiss her knowledge and, thus, continue to wrong her as a knower or transmitter of knowledge.

For Fricker, epistemic injustice constitutes two types of injustices, testimonial and hermeneutical; however, Pohlhaus's analysis of the dialectical relation between situatedness and interdependence reveals a third form of epistemic injustice as outlined in the subsequent premises:

P7. Marginalized knowers can achieve robust understandings of their experiences even while their experiences remain misunderstood and/or obscured from the hermeneutically dominant and powerful (723). P8. Dominantly situated knowers can, and sometimes do, learn to have a more objective perspective of the world when they learn to use epistemic resources of the marginally situated. This fact reveals another type of epistemic injustice, willful hermeneutical ignorance (722).

P9. Willful hermeneutical ignorance reveals that, regardless of the intelligibility, dominantly situated knowers may continue to preemptively dismiss or refuse the epistemic resources of the marginally situated person and, thus, wrong her as a knower or transmitter of knowledge. This requires an active ignorance on the part of the dominantly situated (722). 
The relations of power and privilege that support willful hermeneutical ignorance should not be understated. To this end, Pohlhaus calls attention to the power that dominantly situated individuals have in choosing to ignore certain parts of the world; they have the power to refuse and disqualify marginalized knowers. This fact brings us to the full force of willful hermeneutical ignorance in Pohlhaus's final amendment to Fricker's account. We need to add a P10 to highlight how in refusing to acknowledge the epistemic resources of the marginalized, dominantly situated knowers use the power of their social position in the "circuitry of interdependence" to undermine the marginalized knower as a knower (729). For Pohlhaus, enacting refusal in this way is willful.

P10. "In cases where such a refusal is enacted, dominant epistemic agents are calling for a guarantor for the need for new epistemic resources, but they disqualify marginalized knowers, the very persons whose experienced world reveals the inadequacy of current epistemic resources. An en masse refusal to recognize alternate epistemic resources, when enacted by those with material power, is hard to overcome" (Pohlhaus 2012, 729).

Unlike Fricker, Pohlhaus crucially recognizes that dominantly situated knowers can assert their positions of privilege and power by maintaining ignorance of the ways in which the world is revealed to those in the margins. On Pohlhaus's account, if the dominantly positioned take an active interest in how the world is revealed from marginalized experiences, there is an opportunity to fill in some hermeneutical gaps. Pohlhaus writes that "ignorance is not something to which one is doomed because of social position but rather something one chooses to maintain (Pohlhaus 2012 731; my emphasis). 
Medina's work further complements and builds on Pohlhaus' by introducing how insensitive communicative dynamics between people create hermeneutical gaps and maintain hermeneutical marginalization (Medina 2012, 202-206). For Medina, hermeneutical and testimonial injustice "converge and feed each other" when a particular group of people fail to be sensitive to the testimonies of another group, perhaps due to difficulty in hearing and interpretation (206). He calls this phenomenon "communicative interactionism," and he uses the concept of "White ignorance" to show how White folk protect themselves from confronting their privilege and complicity in the oppression of and interactions with others. According to Medina, individuals who evoke or rely on such ignorance are "co-perpetrators" of hermeneutical injustice (with or without their knowledge or intentions) (218).

I argue that Pohlhaus's definition of willful hermeneutical ignorance and her thesis of the dialectical relation between situatedness and interdependence along with Medina's account of communicative interactionism merge and reveal four important factors about willful hermeneutical injustice: 1) that ignorance is active/willful, 2) that it has psychological and sociopolitical roots, 3) that we enact and rely on hermeneutical gaps through the ways in which we communicate and sometimes silence/dismiss people in and through the relationships we have with them, and that 4) we have a hermeneutical responsibility to do something about it (Medina 2012, 206-217). I will expound on these four features of willful hermeneutical ignorance in the sections that follow. To do so, I look specifically at White ignorance as a central case of willful hermeneutical ignorance for Pohlhaus and Medina. As such, the following sections will draw on Medina and 
Pohlhaus, as well as Charles Mills and W.E.B. Du Bois for their work expounding White ignorance.

\subsection{How Ignorance is Active and Willful}

So far, I have outlined how Pohlhaus suggests amendments to Fricker's accounts of epistemic injustice. Pohlhaus recognizes how the interdependence we have in creating, disseminating, preserving, and recalibrating epistemic resources are shaped in relations of power and can lead to the powerful willfully ignoring the epistemic resources of the marginalized. Medina further critiques Fricker for failing to consider how agents contribute to hermeneutical injustice. Recall in section 2.1 that Fricker treats hermeneutical injustice as a structural problem. This indicates that while a single agent can be the perpetrator or victim of testimonial injustice, a single agent cannot perform or perpetrate hermeneutical injustices. However, Medina maintains that agents are "coperpetrators" of hermeneutical injustice, with or without their knowledge or intention (Medina 2012, 218). This assertion challenges Fricker's claim that there are no individual perpetrators of hermeneutical injustice and that there is no link between communicative relationships between people or among social groups of people (Fricker 2007, 159). Medina uses his framework of "communicative interactionism" to argue that dominantly situated knowers are emboldened to ignore the experiences of the marginalized by way of cultivating particular habits or "vices," such as a lack of hermeneutical alertness and insensitivity performed in communication with those marginally situated (Medina 2012, 218). Moreover, Medina asserts that dominantly situated knowers are often encouraged to develop specific epistemic habits/vices such as epistemic arrogance, close-mindedness, and laziness when confronted with interpretive resources of the marginalized and "with 
regard to knowing the world well in light of those oppressed" (Pohlhaus 2017, 17). Ultimately, these habits/vices sustain a type of "active ignorance" and "interpretive impoverishment" for dominantly situated knowers (212-213).

Medina highlights how the communicative dynamic in the interactive relationships between dominantly and marginally situated knowers involves several factors that Fricker fails to acknowledge as relevant. Medina's thesis of communicative interactionism can be summarized as such:

MP1. There are communicative/testimonial dynamics that can be silencing, constricting, excluding and/or otherwise minimizing certain voices (203-206).

MP2. These dynamics are a result of individuals and groups failing to be reciprocally responsive, open, or sensitive to each other (207-211). MP3. Individuals and groups have an interactive and performative responsibility to be responsive, open, and sensitive to each other through the "speech acts" of their daily lives so that we may "take responsibility for how our communicative agency relates to the blind-spots of our social practices" (216). Doing so would mean that one is being hermeneutically sensitive.

MP4. Poor communicative/testimonial dynamics between individuals and groups (characterized by a lack of responsiveness, openness, and sensitivity) will result in hermeneutical insensitivities that further maintain the presence of hermeneutical gaps among the individuals and groups involved. 
MP5. Hermeneutical gaps must be understood in terms of failed communicative/testimonial dynamics because it uncovers the relational contexts which tell us important information on "who is communicating (or trying to communicate) what to whom" (207).

Premises 1 through 4 recognize that the communication that happens between marginally and dominantly situated knowers is influenced by dynamics of power and privilege that already exist prior to attempts to communicate. On Medina's account, in a communicative interaction, the dominantly situated may not be listening, hearing, or interpreting well due to dynamics of power and privilege (consider again the example I discussed in an earlier section of a male doctor whose identity prejudice towards POC women informs his decisions to dismiss her health concerns) (206). The consequences of this dynamic may be silencing, constricting, minimizing, or otherwise misconstruing of the marginally situated who is communicating or trying to communicate. Premise 4 explains how such insensitivities on the part of the hearer/dominantly situated can then merge with hermeneutical insensitivities. This perspective is an important departure from Fricker's account since she takes testimonial and hermeneutical injustices to be different in when and how they occur. Medina recognizes that dominantly situated individuals or groups who have poor communicative dynamics (as described by premises 1,2, and 4) may perform testimonial insensitivities, which, in turn, contribute to gaps in the hermeneutical resources between them and the marginally situated. To expand the case of willful/active ignorance more clearly, I outline the case of White ignorance below. 


\subsubsection{Pohlhaus's and Medina's central case: White Ignorance}

While Pohlhaus deals with the topic indirectly, both she and Medina develop their arguments for willful ignorance and communicative interactionism through the examination of racially privileged, ignorant White subjects and White ignorance (predominantly in the context of the U.S.). White ignorance is a type of ignorance exercised by White (and non-White) people that is linked with White supremacy and supports false beliefs as well as an absence of knowledge about people of color (Sullivan and Tuana 2007, 3). Charles Mills argues that White ignorance stems from the inability to recognize one's own racial identity and the consequences of one's racial position (Mills 1997, 17-19). In this case, the situatedness of White people is shaped by their race and a complex history of White supremacy. In relation to people of color, their history of White supremacy positions them as privileged and dominantly situated individuals with material and hermeneutical power. Mills argues that the White people's experience in the White world revolves around a cultivated White blindness that does not make marginalized experiences salient (Mills 2007, 19-28). This experience results in a racial blindness in the epistemic resources they cultivate. Thus, White people can assert their positions of privilege and power by maintaining ignorance of the ways in which the world is revealed to Black people, for example.

Consequently, consider the relationship between White and Black Americans. Many White people in America are unequipped to understand marginalized worlds, or even the worlds of those who are "forced to live in two worlds," where one is what they are subjected to (and even oppressed by), and the other is one "they created, the one they served and the alternative one they could call home" (Medina 2012, 211). Here, Du Bois 
explains that while White Americans exhibited a kind of blindness in the world they had created, Black Americans developed a "double consciousness" (Du Bois 2007, xiii). The double consciousness/vision of Black Americans allows insights into both their own world and the world of the American White population. Pohlhaus captures this phenomenon in her analysis of the dialectical relationship between situatedness and interdependence and in her use of insights from feminist standpoint theory.

Recall that, according to Pohlhaus, marginalized knowers are required to use and be aware of dominant/collective epistemic resources, but they will also find gaps in the collective/dominant epistemic resources for making sense of their marginalized experiences. However, this is not to say that they cannot achieve robust understandings of their experiences vis-à-vis the creation of their own resources interdependently within their communities. The fact that such epistemic resources are obscured from the hermeneutically dominant does not mean that they do not exist. As the Du Bois quotation indicates, double consciousness arises for Black Americans because of being subjected to the epistemic resources of the dominant interpretive resources, as well as having insights into their own world, a world obscured to the dominant and powerful because of their racial blindness. On Pohlhaus's account, racial blindness reflects the White American failure to be epistemically interdependent with non-White—-specifically Black— Americans by refusing to acknowledge them as valid knowers.

Following Du Bois, Medina accounts for racially privileged subjects, such as White Americans, in terms of their being hermeneutically insensitive. For Medina, the self-ignorance they have in interpreting racial matters undermines their hermeneutical sensibilities in the way they communicate with others. Here, a lack of responsiveness, 
openness, and sensitivity by White Americans to the unsettling realities of how Whiteness has been and remains oppressive to Black Americans maintains the presence of hermeneutical gaps where the experiences of Black Americans are ignored, and the belief is that this exclusion is justified. For Medina, these hermeneutical gaps are a result of failed communicative/testimonial dynamics between White and Black Americans. Medina's account of communicative interactionism indicates that Black American voices are silenced, constrained, minimized, or seen as unimportant when they reveal their racialized experiences to White Americans. Thus, hermeneutical gaps about the Black experience in the collective resources are performed and reenacted by White Americans exercising a choice to remain ignorant/dismissive of epistemic resources that reveal the Black worlds they have benefitted from through marginalization. They are, in Pohlhaus's account, engaged in and guilty of willful hermeneutical ignorance.

Charles Mills explains that in America, White ignorance comes from a distorted reality shaped by a history of White supremacy; this history distorts memories of the past by ignoring White America's racism (Mills 2007, 15-21). White ignorance functions as a "collective amnesia" about the racism of the past, about how it is still present, and about who benefits from it (Mills 2007, 28-29). Subsequently, the hermeneutical insensitivities that White Americans have towards Black Americans is indicative of this curated social memory that does not acknowledge the crimes of White supremacy and White privilege. For Medina, this gap in understanding their social position explains why White Americans can often be silencing, constricting, excluding and/or otherwise minimizing of the testimony and credibility of non-White people that challenge their social memory or their limited understanding of the world beyond their purview. In Pohlhaus's account, 
White people can (and sometimes do) take an active interest in how the world is experienced by Black Americans and, thus, there can be opportunities to fill in some hermeneutical gaps. Lastly, for both Pohlhaus and Medina, no one is doomed to White ignorance or to a willfulness with respect to not knowing how the world is experienced by the marginalized; it is something White subjects can address via attuning to their social, epistemological, and communicative relationships with non-White/Black people. In the final chapter, I will return to these points to build a positive account of what can emerge when willful ignorance changes to a willful knowing.

\subsection{Situating Ignorance in Canada's Settler Colonial Context}

The primary focus of this chapter has been to expound on how both the positionality and relationality of groups and individuals are influencing factors in instigating and sustaining willful hermeneutical ignorance and to identify this as a distinct type of epistemic injustice. In the remainder of this thesis, I will argue that willful hermeneutical ignorance most appropriately represents the epistemic injustice that occurs in the colonial relationships that exist within a settler-colonial state. More specifically, I look at the colonial relationship between settlers and Indigenous people who inhabit Turtle Island. ${ }^{5}$ To do so, I draw on the work of Koggel, who argues that the dominant epistemic resources of the settler state reflect the settler-colonizers' world. In “Epistemic Injustice in a Settler Nation: Canada's History of Erasing, Silencing, Marginalizing,” Koggel argues that although Indigenous communities have their own developed interpretive resources for knowing the world, these resources "make little or no sense to nonIndigenous Canadians" (Koggel 2018, 241). Koggel highlights how settlers have

${ }^{5}$ Turtle Island refers to North America. It is what many Indigenous communities called this geography before it was renamed by settlers. 
disregarded Indigenous ways of knowing as evidenced through assimilationist government policies and institutions such as the Indian Act and Residential Schools in order to occupy the dominant hermeneutical space with Western systems of knowledge (249). Departing from Fricker's conception of hermeneutical injustice, Koggel explains hermeneutical gaps in the Canadian context as ones that result from the "powerful creating and controlling the dominant collective interpretive resources so that the collective interpretive resources of the less powerful are explicitly or implicitly ignored, dismissed, marginalized or silenced” (Koggel 2019, 2). She states, It is not that Indigenous peoples cannot make sense of their social experiences, but that the collective interpretative resources they call on make little or no sense to non-Indigenous Canadians. Their collective interpretative resources were not deemed to be resources and were openly targeted for erasure through the Indian Residential Schools systems. Their collective interpretative resources have had to be remembered, retrieved, and recorded by the many people in communities of Indigenous peoples across Canada. (Koggel 2018, 241)

This argument is the basis of a substantial critique of how Canada's dominant collective interpretive resources reflect "attempts to denigrate, dismiss, and erase Indigenous laws, practices, languages and traditions," which have caused lasting hermeneutical gaps in the dominant collective interpretive resources of Canadian society (Koggel 2019, 1). Subsequently, Koggel argues that hermeneutical injustice is at the heart of many foundational and structural injustices that affect Indigenous people's agency, participation, and self-determination in Canadian society (Koggel 2019). 
Note that Koggel's approach places importance on understanding how Indigenous and non-Indigenous relationships have been shaped and continue to be shaped by an ongoing history of settler colonialism and the "gross violations of human rights emerging from the past and continuing into the present" (Koggel 2018, 3). In this thesis, I build on Koggel's insights about what emerges from the past in each chapter to argue that willful hermeneutical ignorance, when merged with Medina's communicative interactionism, presents us with the most appropriate entry point to analyze how epistemic injustice persists between settlers and Indigenous people. In doing so, I will develop and expand Pohlhaus's and Medina's relational approach to capture specific strategies and characteristics of the willful ignorance that settler-colonizers perpetrate against the legitimacy and understanding of Indigenous epistemic resources. In the chapter that follows, I take Koggel's lead in unpacking the historical events that have created the current collective interpretive resources that ignore Indigenous peoples' voices and experiences. 


\section{Chapter 3: Settler-colonialism as the Ontological Framework for Understanding Settler-Indigenous and Arrivant-Indigenous \\ Relationships in Canada}

\subsection{A Note on Terminology}

I use 'non-Indigenous' to name all people who are not Indigenous to Turtle Island. I draw on Chelsea Vowel's (Métis) example by using 'settler-colonizers' to name "the nonIndigenous peoples living in Canada who form the European-descended sociopolitical majority" (Vowel, 2020). I use this term to refer to White/European settlers who originate from Europe and have, through various methods of colonization, instated their systems, laws, and customs to create the Canadian state and impose it on Indigenous peoples, as well as other racialized migrants (Vowel, 2020). I use the terms 'Indian' and 'Aboriginal' only when referring to legal or historical titles and documents such as Aboriginal title and the Indian Act.

Note that for my purposes, it is necessary to make a distinction between White/European settler society, Indigenous society, and racialized immigrant society to capture the role of European settler-colonial history, privilege, power, and positionality in the creation and maintenance of settler-colonialism in 'Canada.' Consequently, I follow Sherene Razack's use of the term "White settler society" to signify the role of racial hierarchies in creating and maintaining the Canadian state (Razack 2002, 1-2). I will use this narrow term in my thesis only when drawing attention specifically to the role of racial hierarchy, White supremacy, and the position of White settlers with respect to Indigenous and racialized people. 
When addressing racialized peoples living on the land that is now called Canada, I draw from Jodi A. Byrd (Chickasaw Nation) in distinguishing between Indigenous peoples, settler-colonizers, and what she terms as "arrivants." Arrivants captures the idea that racialized settlers are subjected to pre-established settler-colonial systems, laws, and customs because of their migration and settlement (Byrd 2011, xix). As Byrd puts it, "Of particular concern is how to theorize the degrees to which indigenous peoples, settlers, and arrivants - a term I borrow from African Caribbean poet Kamau Brathwaite to signify those people forced into the Americas through the violence of European and Anglo-American colonialism and imperialism around the globe-have functioned within and have resisted the historical project of the colonization of the "New World"' (Byrd 2011, xix). Although Byrd refers specifically to descendants of African enslaved peoples as 'arrivants', I borrow her term to recognize the ongoing effects of colonialism and imperialism around the globe, and more specifically, in the context of how racialized migrant communities are situated on this land that is called Canada and in their relationship to White settler society and Indigenous communities. For the purposes of this project, my use of the term 'arrivant' is only intended to capture how colonialism and imperialism impact the racial/social/epistemic positionality of racialized migrants in the context of Canada's diverse and pluralistic landscape. ${ }^{6}$ Here, it should be noted that when I use this narrowed version of the term 'arrivant', I do not intend to make invisible the distinct history and legacy of slavery that impacts the way descendants of African

\footnotetext{
${ }^{6}$ Note that although I refer to racialized migrants broadly when using the term 'arrivant', there are significant variations in how different 'arrivants' are situated (ie. they can be economic migrants, refugees, environmentally displaced migrants etc.). Case specific investigations of such pluralities in the broader arrivant community is needed to have a detailed account of the nature of their relationship to White settler society, Indigenous communities, other migrant communities, and the performative and interactive they may play in the marginalization of Indigenous knowers. Such an investigation is beyond the scope of my thesis.
} 
enslaved people are situated on this land. Investigating the history and legacy of African slavery and settler colonialism in Canada in the context of descendants' racial/social/epistemic positionality in relation to White settler society and Indigenous communities is an important project that is beyond the scope of my thesis.

\subsection{Canada's Settler-Colonial History}

In Settler Colonialism and the Transformation of Anthropology, Patrick Wolfe maintains that a "greed for land" and a "logic of elimination" to displace Indigenous societies from their land is the motive of settler-colonization (Wolfe 1999, 27). Here, he explains that rather than race, religion, advancing civilization, or labor, the irreducible element of settler-colonialism is defined by the accumulation of land. He further characterizes settler-colonialism as premised on 1) displacing Indigenous people off their land, 2) eliminating Indigenous communities, and 3) maintaining an invasion of the land that is to be understood as a 'structure' and not an event (1-29). The occurrence of these three facets of settler-colonization is tied to what Wolfe terms "the logic of elimination," which "strives to replace indigenous society with that imported by the colonizers" through the three elements outlined above (27).

Wolfe's characterization of settler-colonialism highlights the importance of land as the central issue in settler-colonialism. To this end, Audra Simpson (Mohawk) summarizes that the European entitlement and desire for land produces what is culturally known in Canada as the "Indian Problem," where the question for settler-colonizers becomes what to do about Indigenous communities and what to do "with their souls, their bodies, their culture, and their difference" (Simpson 2014, 19). Historically, we have seen the answer to be corporeally violent methods of land dispossession, genocide, forced 
assimilation, and the subsequent hermeneutical exclusion and disempowerment of Indigenous people. To know the world in which Indigenous people are situated, settlercolonizers and arrivants must first make sense of these experiences.

Recall from Chapter 2 where I drew on the work of Pohlhaus and Medina to highlight how positionality and relationality are crucial in instigating and sustaining hermeneutical injustice caused by willful ignorance. Canada's history of settlercolonialism reveals to us a particular positionality of White/European settlers in their relationships to Indigenous people in 'Canada.' Understanding the history of this land and its first peoples is important because it allows us to understand the position settlercolonizers and arrivants have in relation to Indigenous people. For my purposes, understanding the positionality of each group in this way is important because it explains the material and hermeneutical power settler-colonizers and arrivants have over Indigenous people and communities. As Glen Sean Coulthard (Yellowknife Dene) explains, in 'Canada,' land can be understood "as an ontological framework for understanding relationships" $(2014,60)$. For this reason, the first step in tracing willful ignorance in the relationship between settler-colonizers and Indigenous communities starts with the unpacking of the historical (and ongoing) invasion (as a structure, not a singular event) of Indigenous land, the dispossession of Indigenous land, and the elimination of Indigenous peoples by settler-colonizers.

In what follows, I unpack the nature of historical injustice between settlercolonizer and Indigenous communities in the context of Canada as a settler nation by developing and applying Wolfe's three elements of settler-colonialism: 1) looking at how the Doctrine of Discovery and terra nullius displaced and continues to dispossess 
Indigenous people of their land; 2) outlining various forces of elimination towards Indigenous communities, such as Indian residential schools, disease and war; and 3) exploring how the Doctrine of Discovery, Indian residential schools, and early aspects of attempted elimination need to be understood as a 'structure' and not events. In unpacking this history, my aim will be to highlight how landmark events of Canada's setter colonization serve as the basis for the material and hermeneutical dominance of colonizers and arrivants over Indigenous communities. Examining this history will also allow me to establish how settler-colonial society has been able to systemically eliminate the hermeneutical participation and resources of Indigenous peoples.

The concept of willful ignorance can then be called on in Chapter 5 to describe in greater detail the current settler-colonial relationships with Indigenous peoples. By calling on the work of Pohlhaus and Medina, I will argue that the settler mindset that leads to the erasing and silencing of Indigenous people and communities can only be done through negating one's dialectical relationship with Indigenous people. I will present this argument in Chapter 4 in part by referring to the work of Koggel (2018), who uses the example of Canada's forced assimilation of Indigenous children through Residential schools as a way of managing the "Indian Problem," and as former Prime Minister Stephen Harper noted in his apology, for the then-government-stated-policy of "killing the Indian in the child" and erasing/silencing Indigenous hermeneutical resources (244). 


\subsection{Displacing Indigenous People off their Land: Doctrine of Discovery and terra}

\section{nullius}

In Indigenous Peoples, Anthropology and the Legacy of Epistemic Injustice, Rebecca Tsosie (Yaqui) defines the Doctrine of Discovery as "a legal fiction developed by the European nations to claim ownership of land, resources, and human labor in the New World" (Tsosie 2018, 357). Simply put, this doctrine was premised upon the false, racist, and Eurocentric views that Europeans held superior rights because they saw themselves as more 'civilized' in contrast to Indigenous peoples, who were deemed 'uncivilized' and unable to own property. Western eighteenth-century views on property and ownership were key factors during the time of European 'discovery' and provided the racist spiritual, moral, and legal basis for land dispossession. The logic of the Doctrine of Discovery comes from the spiritual and political positioning of Christian colonizers to have legal justification over land uninhabited by Christians. It is derived from papal bulls (formal statements made by the Pope) in the 1400s which would grant most of North and South American land to Spain (Truth and Reconciliation Commission [TRC] 2015b, 46). Consider the following excerpt from the 1493 papal bull delivered by Pope Alexander VI titled "Inter Caetera" that grants colonizers authority to claim land and spread Christianity:

All in order that you may enter upon so great an undertaking with greater readiness and heartiness endowed with the benefit of our apostolic favor, we [Pope and Catholic Church] of our own accord, not at your instance nor the request of anyone else in your regard ... give, grant, and assign to you and your heirs and successors ... forever, together with all their 
[Indigenous peoples'] dominions, cities, camps, places, and villages, and all rights, jurisdictions, and appurtenances, all islands and mainlands found and to be found, discovered and to be discovered.

(Pope Alexander VI, 1493)

During this time, the Roman Catholic Church viewed itself as "the guardian of a universal world order" (TRC 2015b, 46). As a result, European Christians used their perceived racial superiority to justify numerous colonial political and legal arguments associated with the Doctrine of Discovery (TRC 2015b, 50). For example, one argument purports that the Christian God gave Christians the right to colonize others' lands in the mission of converting their Indigenous populations (46). European rulers who rejected the Pope's authority to give away sovereignty over half the world modified his decrees and relied more on the legal arguments supporting the Doctrine of Discovery, notions of taking possession after discovery, and the logic of terra nullius - a principle that purports that no one owned the land before colonizers claimed it (45-50). This is the basis for British settler-colonizers feeling justified in claiming North America as "legally vacant" land by using the rationalization of terra nullius at the time of acquisition.

This ideology around land came with what Wolfe explains as a twofold criterion: material/technical and political/regulative. He explains that for the first criterion, land must be transformed from its natural state with labor to make it a "more efficient provider for human subsistence" (Wolfe 1999, 26). ${ }^{7}$ Next, there needed to be a system that recognized this improvement and provided sanctions to those who improved the land to privatize it. Lastly, to legitimize private property, there needs to be a centralized

\footnotetext{
${ }^{7}$ This could be European-style agriculture (TRC 2015b, 46).
} 
government that can police and enforce boundaries on the land (Wolfe 1999, 26). Thus, despite Indigenous people living on the land and having their own forms of governance, settler-colonizers took the lack of regulated private property as a sign that it was open for their taking. The presence of Indigenous people on Indigenous land did not void claims of terra nullius because, to Europeans, Indigenous people were merely occupants. In the Europeans' view, Indigenous societies were "so low on the natural scale of social and cultural evolution" that they did not/could not own land (Coulthard 2014, 100). Instead, ownership could only be classified through the European bourgeois style of material, regulative, and privatized conditions.

The Doctrine of Discovery (and related concepts) serve as the foundation upon which the legitimacy of the Canadian state now relies. This is so despite a statement issued by the UN representative from the Roman Catholic Vatican in April 2010. The statement notes that the papal bulls regarding "territorial expansion and the forced conversion of Indigenous peoples had subsequently been abrogated or annulled by the Roman Catholic Church" and were annulled by other subsequent papal bulls (TRC 2015a, 6:30-31). For many, this papal renunciation was not enough considering the immense harm it has caused and its current influence in Western law (31). To this end, Michael Asch outlines the presumptions and presence of the Doctrine of Discovery in the Canadian judicial system in the following way.

1. Sovereignty and legislative power are vested in the British Crown.

2. Ownership of Aboriginal lands accompanies sovereignty over Aboriginal territory. 
3. Aboriginal peoples have an interest in land arising from original occupation that is less than full ownership.

4. The British Crown obtained the sole right to acquire the Aboriginal interest.

5. Aboriginal sovereignty was necessarily diminished.

(Asch 1998, 47)

One way the Doctrine of Discovery continues to affect Indigenous communities today is how, because of its legacy, Indigenous communities must "prove their pre-existing occupation of the land in court cases in order to avoid having their land and resource rights extinguished in contemporary Treaty and land claims processes" (TRC 2015a, 6:32-33). Historian Jennifer Reid explains how property and land rights are still connected to Christian theology by stating that it "underlies their legal relationships to this day, having smoothly and relatively uncritically transitioned from Roman Catholic to international law" (TRC 2015a, 6:31). In this way, the Doctrine of Discovery provided a framework to claim territories uninhabited by Christians. The underlying presumptions of terra nullius and Doctrine of Discovery shaped Canadian law in ways that could then "justify the unequal distribution of sovereignty that structures the relationship between Indigenous peoples and Canada" (Coulthard 2014, 100).

Today, the legacy of the Doctrine of Discovery and terra nullius in Canadian law requires Indigenous people to prove their pre-existence on their own land. This effect can be seen in several court cases by Indigenous communities filed against the state to "avoid having their land and resource rights extinguished in contemporary land processes" (TRC 2015a, 32-33). A striking example of this conflict can be seen in the first comprehensive land claim made by the Cree of James Bay and Inuit of Northern Quebec in 1975. This 
land claim was in response to the development of the James Bay project, which sought to install hydroelectric dams on unceded Cree and Inuit land without their consent. Consider how signatory to the 1975 James Bay and Northern Québec Agreement Zebedee Nunguk (Inuit) recounts his experiences during the negotiation process:

The Trials and tribulations experienced by the Inuit of the Nunavik in those negotiations have their roots in colonial history. Negotiations were not conducted on a clean, pre-colonial state. The starting clock could not be set back to the day before a colonial act by a foreign king colored our ancestral lands British red for all time on that day in $1670 \ldots$. When the Cree of James Bay and Inuit of Nunavik finally sat down with governments in 1974, these governments held absolute power over all the land in question. They felt legally and constitutionally self-enabled to extract extreme concessions from Cree and Inuit. This they did by requiring them to "extinguish and surrender aboriginal title in and to the land in dispute.' (Nungak 2017, 81-82)

After four years of negotiations, The James Bay Northern Quebec Agreement was finally signed. Feeling as though they were defending their rights "under impossible conditions" and being "forced through the hoops of extinguishment," the Cree and Inuit conceded sovereignty and the hydroelectric dams were built in exchange for access to health care and monetary compensation (Nungak 2017, 111-112).

More recently, Indigenous peoples continue to assert Aboriginal title and treaty rights against colonial law and intimidation. Consider the case of the Haudenosaunee in Caledonia, Ontario. In 1784, the governor of Quebec signed the Haldimand 
Proclamation, which granted a tract of land to the Haudenosaunee as compensation for their alliance with the British during the American Revolution (Canadian Encyclopedia 2016). However, they gradually lost control over this tract of land through colonial violence and government encroachment over the last 230 years (2016). Currently, land defenders from Six Nations are protesting the illegal McKenzie Meadows residential development project on their unceded land. They occupy this site and have renamed it as "1492 Land Back Lane." Unsurprisingly, their fight to protect their sovereignty over the remainder of their land in Caledonia has been met with intimidation and criminalization by the police and the Ontario Supreme Court. On July 31st, 2020, the Ontario Supreme Court served an injunction against the land defenders. The province then spent a staggering sum of $\$ 16.3$ million (in half a year) to police them (Forester 2021). In response, Skyler Williams, a spokesperson for the land defenders at 1492 Land Back Lane, stated that "ideally, courts would recognize the long history of injustices that have been committed against the Haudenosaunee, but once again we face an ultimatum that leaves us with hard choices: enter into a colonial process and watch as our lands get developed or stay on our territory and face police violence" (Patterson 2020).

It is important to note that the influence, legacy, and application of the Doctrine of Discovery, terra nullius, and settler colonial law stand in the way of Indigenous claims to land and to sovereignty in both cases outlined above. The decision to resume development on Cree and Inuit land came after the courts relied on pre-confederate legal interpretations that intentionally overlook mentions of Aboriginal land rights in legal documents $^{8}$ and other federal decisions that recognized Aboriginal title to land. Similarly,

\footnotetext{
${ }^{8}$ Section 2(c) of The Quebec Boundaries Extension Act, 1912 and section 91 (24) of the British North America Act.
} 
the decision to criminalize land defenders with an injunction and to spend tens of millions of dollars on the protection of a development project cannot be made independently of the precedent that the logic of Doctrine of Discovery and of terra nullius has been cemented in Canadian law. In fact, the idea of what is considered legitimate ownership of land in both cases reinforces the criteria that early settlers used in determining whether or not Indigenous communities could and should have ownership of their land: 1) that land must be transformed through development projects (hydroelectric dams and housing) to make it productive ${ }^{9} ; 2$ ) that the state (at various levels) recognizes this improvement and provides sanctions to those who have improved the land to privatize it (Hydro-Québec and McKenzie Meadows); and 3) that centralized government is used to police and enforce boundaries on the land and protect private property (court injunctions to stop protests and authorizing the OPP to police protestors).

\subsection{Residential Schools and Acts of Elimination}

The underlying arguments that support the Doctrine of Discovery, terra nullius, and the Christianization of Indigenous communities (and all other related concepts/ideologies used to justify colonization) were rooted in deeply racist/othering views of Indigenous people. During this time, to be Christian was to be civilized. To White settler-colonizers, Indigenous people were 'savages' in need of this civilization and salvation ${ }^{10}$ from their culture. As a result, not only did the church justify the colonization of other people's land, but they also sent missionaries to their colonies to "convert the heathen" (TRC

\footnotetext{
${ }^{9}$ The Court ruled that the benefits that the Quebecois would enjoy from the hydroelectric dams had precedence over respecting Indigenous rights. The developers of the Mckenzie Meadows development project aim to create a minimum of 700 residential units.

${ }^{10}$ Christian Missionaries thought Indigenous cultures are "a barrier" to spiritual salvation and their 'civilization' (TRC 2015b, 49).
} 
2015b, 48). It was thought that White settler society could raise the rest of the world up to their level (47). In the nineteenth century, this racism also extended to the realm of science, which positioned White society as superior to "less-developed people," who were incapable of improvement (47). In Canada, such racist views in religion and scientific studies directly informed the establishment of Indian Residential Schools.

Prior to confederation, Roman Catholic and Protestant missionaries tried to establish residential schools to civilize and convert Indigenous boys. This venture was ultimately unsuccessful because parents were reluctant to send their children away, and students would often run away (TRC 2015b, 50). However, starting in the 1880s, settlercolonizers ${ }^{11}$ sought to assimilate Indigenous children by eventually mandating their attendance in residential schools through the Indian Act of 1876. As a result, over 130 residential schools were established by the federal government and run by various churches between 1831 and 1996. In short, these residential schools were created to separate Indigenous children from their families, culture, languages, and identities. During this time, settler-colonizers deemed Indigenous parents as unfit to care for and teach their children (4). Thus, the strategy to assimilate and 'civilize' children was to take children from their parents (sometimes with force) at a vulnerable age in order to weaken their familial, linguistic, and cultural ties. Once children arrived at the school, brothers and sisters were kept apart to ensure the erasure of their Indigenous culture and connections as best as they could (4). Government officials went as far as to forbid children from speaking their own languages or practicing their own cultural and spiritual traditions (4). These children were subsequently forced to exist in an institution that

\footnotetext{
${ }^{11}$ Residential schools were federally funded and operated by the Canadian government and Roman Catholic, Anglican, Methodist, Presbyterian and United churches.
} 
would neglect them and provide them with very poor living conditions. These conditions created situations where students were prey to sexual, physical, emotional, and spiritual abuse (TRC 2015b, 4-100). Note that the government and churches were often aware of the abuse that these children faced. While spiritual abuse was mandated, physical and emotional abuse was unregulated, and in cases of sexual abuse, churches often placed their own interests over the interests of the children in their care (105). For example, in some cases, abusers were not even fired after being convicted of their crimes; in other cases, abusers were allowed to avoid prosecution to protect the school's reputation, and many students were told that they were at fault for the abuse they experienced (105). Many schools adopted strict policies of language suppression that demanded students only speak English. Students who came to the schools fluent in their Indigenous language later found it "almost impossible" to communicate with their parents when they could no longer speak in their native tongue. Melvina McNabb, who was enrolled in the File Hills school at seven years old, recounts, “I couldn't talk a word of English. I talked Cree and I was abused for that, hit, and made to try to talk English" (TRC 2015b, 82). Many students, like Melvina, who struggled to speak English, did not speak English or otherwise made grammatical mistakes, were often met with corporal punishment, public humiliation, and even solitary confinement (103-105). Indigenous cultures were also attacked by a curriculum that exclusively focused on teaching them how to be White by explicitly prohibiting all expressions of Indigeneity and implicitly sending messages of White supremacy. To this end, Thaddee Andre, who attended the Sept-Îles, Québec, school in the 1950s, recounts how as a student he wanted to "to resemble the White man, then in the meantime, they are trying by all means to strip you of who you are as an Innu. 
When you are young, you are not aware of what you are losing as a human being" (TRC $2015 \mathrm{~b}, 83)$. In this way, the educational goals of the schools were highly limited to suppressing Indigeneity in favor of Whiteness (6).

The goal of the residential schools in Canada can be seen as twofold: assimilating Indigenous children into White settler society and at the same time erasing their culture, language, spiritual practices, connections to their families, communities, ancestry, and overall Indigenous identity. The abuse and erasure Indigenous children experienced was immensely harmful and have resulted in long-standing effects, such as the loss of language, alienation from their culture and family, poor education, and the resultant spiritual, physical, and emotional trauma survivors and their communities now must carry. At the same time, it is also important to acknowledge that despite the Canadian government's (and White settler society's) venture to eliminate Indigenous culture, knowledge, spirituality, and way of being by targeting the most vulnerable members of their community with reform and abuse of various forms, they did not succeed. Despite such structural and interpersonal forces of elimination from the government, churches, individual school staff and Indian Affairs officers, and all the damages they have caused, Indigenous people and cultures continue to exist. As I pointed out in Chapter 2, section 2.3, they had and continue to have their own collective interpretative resources. That these resources have been retained and continue to exist (at least in some form) shows the strength and power of their collective interpretative resources even in the face of these not being recognized as resources.

Indigenous communities continue to face many issues because of the legacy of eliminating forces such as genocide and residential schools because several complex and 
intersecting factors identified in the history covered in this chapter are at play. While the TRC mentions that more research is needed to elucidate specific converging factors for some adversities that Indigenous communities face today, such as missing and murdered Indigenous girls and women (TRC 2015b, 180), the links are still apparent in many cases, such as lower educational attainment for the children's survivors, which in turn has limited their employment and earning potential (146). Similar issues, such as high suicide rates, lack of healthy self-esteem, and family breakdown, are not personal failings; rather, they are the result of centuries of structured material, physical, spiritual, hermeneutical elimination, and systemic imperialism (385). As such, I want to emphasize that the marginalized positionality of Indigenous communities in 'Canada' is thus violently imposed and deliberately constructed throughout 'Canadian' history.

In Race, Space, Place, and Law, Sherene Razack highlights Canada's mythologies and national stories that enable non-Indigenous people on Turtle Island to think about community and belonging and how it is "deeply spatialized" (Razack 2002, 3). She notes that though this spatial story varies, what stays consistent is that the "story installs Europeans as entitled to the land, a claim that is codified in law" through legal fictions such as the Doctrine of Discovery and terra nullius (3). However, this narrative willfully overlooks how White settler society originates from the dispossession and cultural elimination that emerges from residential schools and other earlier forms of physical elimination of Indigenous populations through mercantile colonialism, disease, and acts of genocide. Examples of the latter that reflect an Indigenous perspective are outlined in chapter 3 of Razack's book, "Rewriting Histories of the Land: Colonization and Indigenous Resistance in Eastern Canada," by Bonita Lawrence (Mi'kmaq). 
Lawrence outlines the experiences of the Mi'kmaq as they resisted English settler-colonizers. She notes that the Mi'kmaq people faced several directed attacks and eliminating forces from the English. For example, during the mid-1600s, British slavers took Indigenous people and sold them in slave markets in the period around 1650 to 1762. And they introduced policies to exterminate the Mi'kmaq after the Mi'kmaq resisted and fought against British encroachment on their land (34). Some of these policies included "distributing poisoned food, trading blankets infected with diseases, and waging ongoing military assaults on civilian populations" (34). She notes that these acts of genocide were in addition to the diseases such as a typhus and smallpox epidemic in 1746 contracted from the English and resulting in the death of one-third of the Mi'kmaq population. In 1749, Edward Cornwallis, a British military officer and 'founding father' of Halifax, issued a scalping proclamation, which offered a bounty to depopulate the surviving Mi'kmaq people. The same policy was issued again by Governor Charles Lawrence in Nova Scotia. Lawrence further explains,

Those who survived this genocide were destitute, left with no food and without the necessary clothing to keep warm in a cold climate. Many were reduced to begging. Thousands died of starvation and exposure until limited poor relief was implemented on a local basis. Others eked out a bare existence selling handicrafts, cutting wood for Whites, or working as prostitutes (which resulted in outbreaks of venereal disease). Those who struggled to acquire individual land plots were denied title; as a result, it was not uncommon for Mi'kmaw families to engage in the backbreaking labour of clearing and planting a patch of land, only to find that when they 
returned from fishing, hunting, or gathering excursions that White squatters had taken the land. When the British opened up the region for White settlement, they refused to set aside land for the Native peoples. In British legal thinking of the day, non-Christians who had been defeated by and were subject to the British had no rights to land under the "Norman Yoke," an aspect of the Doctrine of Discovery that the British inserted for their own benefit. (34-35)

As the Mi'kmaq population was decimated by such targeted acts of genocide, Mi'kmaq leaders petitioned London to obtain a few small reserves (35). Nonetheless, they continued to face violent dispossession from policies that "tried to centralize and liquidate the few reserves that had been created, divide their bands, and dissolve their traditional governance" (35). This continued until the 1752 peace and friendship treaty was signed, which ended the war between the Mi'kmaq people and British colonials.

For the purposes of my thesis, it will be important to unpack and challenge false assumptions in the settler mindset that position White settler society as innocent and having merely settled/developed land. A brief look at Coulthard's Red Skin, White Masks will also reveal what I mentioned earlier: that Indigenous collective interpretative resources have survived these processes and structures of marginalization and attempted erasure. Coulthard's work is important for adding the factor of capitalism to the discussion of phenomena such as the Doctrine of Discovery and terra nullius and moving the examination to features of the contrasting beliefs, laws, traditions, and ways of being of Indigenous peoples. 


\subsection{Land and Connections to Capitalism}

The question of land and its dispossession from Indigenous communities is a recurring struggle between settler-colonizers' claim to Indigenous land and Indigenous peoples' right to land. Coulthard points this out with his account of primitive accumulation appearing in Canada and having more to do with land dispossession than anything else. In Red Skin, White Masks: Rejecting the Colonial Politics of Recognition (2014), Coulthard applies Marx's framework of primitive accumulation to Canada's settlercolonial context by shifting the focus from capitalist relations of accumulation to colonial relations of accumulation. Coulthard argues that primitive accumulation starts first and then continues with the violent dispossession of land. For Coulthard, it is only after (and through) the violent dispossession of land that the mechanisms of economic relations and proletarianization then emerge (Coulthard 2014, 9). As such, primitive accumulation is not rigidly temporal as Marx originally suggests; rather, for Coulthard, the ongoing project of settler-colonialism in Canada shows that violent state dispossession occurs in tandem with the 'silent' mechanisms of economic relations as the primary forces of accumulation (6-13). The history of denying Indigenous communities the rights to their own land supports Coulthard's assertion that it is only after and through the violent dispossession of Indigenous land that the mechanisms of economic relations, such as European-style agriculture, then emerge (9). Thus, Coulthard stresses that it is primarily the dispossession of land that has structured the relationship between Indigenous peoples and the state.

Accordingly, land dispossession is the "dominant background structure shaping the character of the historical relationship between Indigenous peoples and the Canadian 
state" (13). Both cases outlined above and many more like them both historically and in the present affirm this claim. Moreover, Coulthard also argues that "dispossession continues to inform the dominant modes of Indigenous resistance and the critique that this relationship has provoked" (13). Thus, in his account, the continued experience of dispossession is "what also tends to fuel the most common modes of Indigenous resistance to and criticism of the colonial relationship itself," presenting itself as a struggle oriented around the question of land — struggles not only for land but also deeply informed by what the land as a mode of reciprocal relationship (which is itself informed by place-based practices and associated forms of knowledge) ought to teach us about living our lives in relation to one another and our surroundings in a respectful, non-dominating and nonexploitative way. The ethical framework provided by these place-based practices and associated forms of knowledge is what I call "grounded normativity". (60)

It is important to note that the Doctrine of Discovery and other related constructs used to claim Indigenous land align with early Christian assumptions that sharply contrasted with Indigenous spiritual beliefs and knowledge about land (32). Coulthard draws on Lakota philosopher Vine Deloria Jr. to highlight this difference. He explains that rather than just thinking of land for Indigenous communities as "simply some material object of profound importance to Indigenous cultures (although it is this too); instead, it ought to be understood as a field of "relationships of things to each other," and that to Indigenous communities "place is a way of knowing, of experiencing and relating to the world and with others" (61). He explains that land for most Indigenous communities is understood in relational terms that encompass a system of relations with 
material land, people, animals, lakes, and so on. He states that "within this system of relations, human beings are not the only constituent believed to embody spirit or agency. Ethically, this meant that humans held certain obligations to the land, animals, plants, and lakes in much the same way that we hold obligations to other people" (61). These aspects shape the ethical framework that is at the base of what Coulthard means by "grounded normativity" as identified in the quotation above.

The application and continued influence of the Doctrine of Discovery in Canada's ongoing settler-colonial project reveals that settler-colonizers never learned to consider Indigenous land in this way. Instead, legal fictions like the Doctrine of Discovery are fundamentally centered on gaining sovereignty over Indigenous peoples, their lands, and resources through a structured dispossession of their land and resources. Residential schools are still another way in which the attempted erasure of Indigenous beliefs, laws, languages, traditions, and ways of being would and could better ensure the means and ends of capitalist resource extraction and profit motives.

Government bureaucrats, politicians, and setter-colonial publics took on a paternalistic role to reform and civilize Indigenous people to fix their perceived 'Indian' problem. It is in this way that the racist, Eurocentric, and violently opportunistic mindset of settler-colonizers laid the foundation for Canada's history. A large and lengthy discussion of other aspects of this early history will not be covered due to space constraints. One such topic is that of treaties, the contestation and negotiation of which continues today. After their so-called 'discovery,' early settler-colonizers subsequently took extraordinary measures to make treaties that justified settling on Indigenous lands as 
well as creating "legislation and policy designed to regulate and manage Indigenous lives with a view to acculturation and assimilation" (Regan 2010, 91).

Relearning 'Canadian' history from the perspective of Indigenous communities is vital to contest settler history and mythologies that instill and center White settler societies' collective interpretive resources by disregarding Indigenous ones. As Koggel notes with the case of residential schools in particular, "what is missed in the dominant framework is the deeper relational point that we are all shaped by a history of residential schools that had the stated objective, as noted in Prime Minister Harper's apology, 'to kill the Indian in the child"” (Koggel 2018, 244).

In this chapter, we can see that the settler mindset has led to the erasing (through displacement and genocide) and silencing (through seeing them as a 'problem' to be fixed and 'civilized') of Indigenous people and their collective interpretive resources. However, we also see how, despite erasure and marginalization, Indigenous collective interpretative resources continue to survive. Recall that, according to Pohlhaus, marginalized knowers are required to use and be aware of dominant/collective epistemic resources but will also find gaps in the collective/dominant epistemic resources that fail to make sense of their marginalized experiences. Indigenous people on Turtle Island have shown how they continue to achieve robust understandings of their experiences through resistance and creating their own resources interdependently within their communities. The fact that such rich interpretive resources are obscured from the hermeneutically dominant does not mean that they do not exist. In fact, Indigenous communities often hold insights into both their own world and the world of settler-colonizers. 
The history covered in this chapter affirms that Indigenous communities not only notice the inadequacy of the collective epistemic resources that fail to make sense of the parts of the world that the settler-colonizers do not experience, but their vulnerability and forced assimilation have forced them to be aware of the epistemic resources of the settlercolonizer. As argued through Pohlhaus's account in Chapter 2, section 2.1.2.1, this asymmetrical way of knowing has Indigenous people knowing both their own worlds and experiences and those of settlers. With this insight established, we can start to recognize the misunderstandings that settlers have of 'Indigenous issues' in Canada (and 'our' direct influence or complicity in them) as a willful dismissal of Indigenous interpretive resources.

In the following chapter, I focus on unpacking the dialectical relationship between colonizer and the colonized as it has been shaped through factors such as Doctrine of Discovery, terra nullius, residential schools, dispossession of land, and capitalist modes of resource extraction, all of which have resulted in the subsequent nation-building myths now used to obscure these histories and suppress Indigenous collective interpretive resources. The main message is that the early relationships between Indigenous and nonIndigenous peoples in Canada — ones that resulted in the dispossession of land and the resulting willful ignoring of Indigenous beliefs, languages, values, and ways of beinghave shaped and continue to shape relationships in the present. The paternalist and violent settler mindset can only be substantiated and maintained through actively holding one's settler situatedness in higher regard in relation to Indigenous communities. This is a history of violent land dispossession which starts and proceeds simultaneously with the process of forced assimilation, genocide, and marginalization of Indigeneity from 
dominant settler-colonial culture. The deliberate dismissal and willful ignorance of the fact that Indigenous people on Turtle Island had their own notions of organizing, governing, and sovereignty continues in current policies that extol myths and values that 'Canadians' are a benevolent and peacemaking/peacekeeping people. 


\section{Chapter 4: Understanding the Relationships between Colonizer, the}

\section{Colonized, and the Arrivant}

The main purpose of this chapter is to explore relationships shaped by and emerging from assumptions about and histories of the treatment of Indigenous peoples in Canada. In sections 4.1 and 4.2 of this chapter, I investigate the racial/social/epistemic positionality of White settler society and arrivants in Canada as they have emerged from a colonial history that has used mythologies about the land and "savage Indians" to justify attempts to erase Indigenous beliefs, laws, languages, traditions, and ways of being. Working from this historical context, I take a deeper look at how a commitment to national mythologies informs the structural and epistemic situatedness and dialectical relationship of the settler-colonizer relationship with Indigenous communities, as well as of the arrivant relationships with both settler-colonizers and Indigenous communities.

\subsection{How Myths Position White Settler Society as Hermeneutically Dominant: The}

\section{Land, the "Savages," and the Peacemakers}

Building on the insights from the previous chapter, I now show how myths of the land and its 'savage' inhabitants served as the ideological basis of the settler-colonizers' mission to acquire land, displace Indigenous inhabitants, and create the legal fictions still in effect today. It also provides the lens/collective interpretive resources through which White settler-colonizers can perceive the world, themselves, their relationships to Indigenous communities, and their national identity. These mythologies not only portray early settler-colonizers as benevolent and peaceful migrants seeking a more fruitful life via trade and settlement, but they are also significant factors in the assigned political, economic, epistemic, and social superiority of White settler society today. As a result, 
these two myths of benevolence and peacemaking have had an incredible influence on how White settler society historically (and currently) displaced and marginalized Indigenous communities.

On the topic of land, I have outlined a few examples of land dispossession as central in the historical relationship between Indigenous people and settler society. Notions about the emptiness of the land, through concepts of terra nullius and the Doctrine of Discovery and their legal legacy, ignore how White settler society in 'Canada' originates from the dispossession and cultural and physical extermination of Indigenous populations through mercantile colonialism, disease, and acts of genocide. On the topic of settlers' treatment of Indigenous people, I have outlined how a lens of White superiority has led to the systemic dehumanization of Indigenous peoples as a problem to be solved by way of "civilizing" them via conversions to Whiteness. Here, notions about the savagery of Indigenous peoples were engendered from deeply othering views of Indigenous people rooted in ignoring and dismissing Indigenous people as people, as epistemic agents. On the one hand, the imagery of Indigenous land as empty and available for settlers ignores the more violent history of settler colonialism. On the other hand, the imagery of Indigenous inhabitants of Turtle Island as 'savages' allows White settlers to position themselves as agents of civility and benevolence in their relationship to Indigenous communities.

The settler-colonial history in Canada reveals these specific early mythologies that position White settler society as dominantly situated in relation to the Indigenous 'other.' In tandem with these beliefs, the contemporary myth about Canadians' peaceful character emerges and further positions European settlers as wise and paternal bearers of 
civilization, while further trapping Indigenous people in a pre-modern space and time. Unfortunately, such nation-building mythologies are preserved with little to no widespread cultural acknowledgment of the genocide, land dispossession, and various other discrete forms of colonial violence embedded in treaties, policies, policing practices, bureaucratic practices, and claims negotiations controlled and perpetuated by settlers. Instead, they evoke a history that does not acknowledge Indigenous communities, their experiences, and their oppression as salient. This history centers the White settlers in the dominant collective interpretive resources and creates a separate system of historical associations by way of the benevolent and peacekeeping framework and imagery. In the remainder of this chapter, I examine the myth of the benevolent peacemaker and international peacekeeping and how they shape and sustain the dominant collective interpretive resources for all settlers, including arrivants.

\subsubsection{Myths of the benevolent peacemaker}

In her book Unsettling the Settler Within: Indian Residential Schools, Truth Telling, and Reconciliation in Canada, Paulette Regan argues that colonial attitudes and conceptions of Canada's origins as a nation of benevolent peacemakers serve as the "bedrock of settler identity" in Canada (Regan 2010, 11). She argues that this narrative comes from historically comparing Canadian settlement with the violent "Indian wars" of American settlement. She explains that benevolent peacemakers are branded as "neutral arbiters of British law and justice, Christian messengers ... who collaborated in various ways to negotiate treaties and implement Indian policy intended to bestow upon Indigenous people the generous benefits or gifts of peace, order, good government, and Western education" (83). Note that background ideas about the land and its Indigenous inhabitants 
also become the backdrop to the 'benevolent peacemaker' myth. Regan notes that this dominant understanding of Canada's origin reflects this settler understanding of history as real history. She explains that "the peacemaker myth lies at the heart of the settler problem; it informs, however unconsciously, the everyday attitudes and actions of contemporary politicians, policymakers, lawyers, and negotiators, and it remains an archetype of settler benevolence, fairness, and innocence in the Canadian public mind" (87). As a result, we can see how mythologies of this sort help the nation forget its violent past and recontextualize its present. The important point is that this narrow and false story of the past continues to shape and influence settler-Indigenous relationships. One of its powerful effects is the epistemic injustices that result from excluding and misconstruing Indigenous collective interpretative resources as reflected in their worldviews, traditions, laws, and institutions.

Yet, most Canadians ignore the very idea that there are Indigenous collective interpretative resources. A 2016 Environics study found that 61\% of respondents' opinions have not changed despite increased coverage of Indigenous issues (such as coverage on Indian Residential Schools, the TRC, and the Idle No More Movement) in the media and public discourse (Environics Institute 2016, 12). Ten percent of the respondents reported that their opinion worsened in recent years. Fifty-three percent of this group feel that Indigenous people get special treatment from the government, while $44 \%$ have worsened impressions due to stereotypes and perceptions of negative behavior such as laziness (the report phrases this as "not taking advantage of opportunities offered to them to improve their lives"), alcoholism, militant protests, and a "refusal to integrate into mainstream society" (Environics Institute 2016, 13). Twenty-nine percent of this 
group reported "lingering stereotypes and negative portrayal in the media" and negative personal experiences (13). I argue that these statistics about the public opinion toward Indigenous people are, at least in part, a result of how settlers understand themselves and the social position of Indigenous peoples through mythologies that do not properly acknowledge truths about the impacts of epistemic injustices on the material, physical, and spiritual aspects emerging from Canadian government policies that attempted to erase and eliminate Indigeneity. Myths about Canada's benevolence make it especially easy to forget how the marginalized positionality of Indigenous communities in 'Canada' has been violently imposed and deliberately constructed throughout 'Canadian' history via the converging forces of elimination and structured invasion covered in Chapter 2. In reflecting on where such a myth comes from, John Ralston Saul questions, "Where did the concept of peacekeeping come from?" (Saul 2008, 93). He argues that the actual roots of Canadian peacemaking are the result of Indigenous and Native leaders continually offering a vision of reconciliation to Canadians that is based on coexistence and building balanced ongoing relationships but that "we just don't listen" (99). Instead of listening, settlers have appropriated the role of peacemaker in our own version of Canada's history that is not acknowledged as colonial. This narrative erodes our collective ability to be cognizant of the historical and ongoing harms that are faced by Indigenous communities or to be aware of their own rich and oppositional collective interpretative resources. Regan argues that "Regardless of where on the political spectrum settlers may stand concerning Indigenous issues in Canada, the peacemaker myth is at the heart of how we justify our actions" (Regan 2010, 106). 
While the majority ( 84 percent) of respondents report that they believe nonIndigenous people have an individual role in bringing about reconciliation between Indigenous and non-Indigenous people in Canada, 69 percent also agree that most Canadians are prejudiced against Indigenous peoples "whether or not they are conscious of it." Another 75 percent "believe mainstream Canadian society today benefits from ongoing discrimination against Aboriginal peoples" (Environics Institute 2016, 26). However, an Angus Reid survey from 2018 reports that 53 percent of respondents agreed to the following statements: "In modern Canada, Indigenous people should have no special status that other Canadians don't have"; "Canada spends too much time apologizing for residential schools - it's time to move on" (Angus Reid 2015, 1). Considering that many survivors of the Residential schools are still alive today and that, at the time of writing this chapter (from May to June 2021), the bodies of 1,323 Indigenous children were found in six unmarked mass graves at the sites of residential schools all over Canada ${ }^{12}$, it is time that Canada's public understanding of their own attitudes towards Indigenous histories and experiences be revealed. ${ }^{13}$

A national commitment to the benevolent peacemaker myth obscures nonIndigenous Canadians' understanding of settler history. Certainly, we see this impact substantiated by the Environics survey when only 33 percent of respondents agree that "mainstream Canadian society today benefits from ongoing discrimination against

\footnotetext{
${ }^{12} 215$ bodies were found in Kamloops BC. 104 bodies were found in Brandon MB. 35 bodies were found in Lostock SK. 38 bodies were found in Regina SK. 751 bodies were found in Cowessess SK. 180 bodies were found in Carlisle PA, ${ }^{12}$. More bodies of children killed in residential schools are expected to be found as the search for mass unmarked graves continue (as of August 23 $3^{\text {rd }}$, it is said that 5,296 children have been found in unmarked graveyards in Canada and the US).

${ }^{13}$ Some additional issues that have caught mainstream media's attention during this timeframe are how young Indigenous girls (as young as 10 years old) have been forced to have IUDs by social workers in BC as a means of 'rape prevention,' and how babies at residential schools were thrown into furnaces and burned alive.
} 
Aboriginal peoples" (Environics Institute 2016, 28). For this reason, the benevolent peacemaker myth can be understood as an interpretive resource that allows dominantly situated knowers to draw on their positions of privilege and power by maintaining ignorance of the ways in which the world is revealed to and lived by those in the margins. These myths then play a crucial part in Sue Campbell's call for an account of "good remembering" from which to reveal what counts as bad or failed remembering (Campbell 2014, xiv; Koggel 2014). Both Campbell and Koggel connect the notion of good remembering with the goal of alleviating oppression (a remembering of the past in the present and for the future). I will return to the significance of remembering in my discussion of Campbell's work in Chapter 6. In terms of my argument, bad remembering reflects a willful dismissal or refusal of the collective interpretive resources of Indigenous peoples whose histories and experiences do not align with the narratives. In this way, taking on the identity of the benevolent peacemaker requires a willful ignorance that has dominantly situated settlers ignore and dismiss the perspectives and experiences of Indigenous peoples in 'Canada.'

The benevolent peacemaker myth illustrates epistemic injustice in the sense that this willful ignorance wrongs Indigenous peoples as knowers or transmitters of knowledge about their history and life experiences. Consequently, in the settler-colonial context of Canada, celebrating these cultural narratives/mythologies is actively ignoring the epistemic resources of the marginalized in the senses of both testimonial and hermeneutical injustice, but especially of the latter in terms of the history and relationships between Indigenous and non-Indigenous peoples that have emerged from that history. 
Currently, we can see two ways in which settler Canadians in both White settler societies and arrivant societies commit themselves to the identity of the benevolent peacemaker: first, by preserving early settlers' ideologies as a social memory of benevolence through the dual process of willfully ignoring the experiences of Indigenous communities that challenge the narrative; and second, though a denial of their relationality with Indigenous peoples as epistemic agents.

Pohlhaus and Medina's analysis of willful hermeneutical ignorance in the context of 'what we are likely to know' and 'what we are willing to know' can shed some light on why such misleading mythologies not only fueled the early colonial project on Turtle Island but also how such myths have largely become the hermeneutical norm by which Canadians remember and perceive themselves. Next, I explore how arrivants are influenced by the collective interpretive resources created by White settler society by exploring how Canadian-ness and the Canadian mindset are constructed domestically and internationally.

\subsection{The History and Social Positioning of Canada's Myths of Benevolence and Peacemaking}

In chapter one of Unsettling the Settler Within (2010), Paulette Regan identifies herself as a colonizer-perpetrator and colonizer-ally to acknowledge the power, privilege, and complicity she has as a settler in the ongoing colonization of Canada. For Regan, recognizing the role and nature of White settler identity in this way is significant, as it allows settlers to disrupt the "mental, emotional, and material habits" (27) associated with White settlers' dominant position in 'Canada' that subsequently contributes to the marginalization and oppression of Indigenous peoples. 
The previous section, and this chapter more generally, note that this narrative comes from Canadian exceptionalism and the settler identity of the benevolent peacemaker. This section looks at Canadian internationalism and Canada's contributions in pioneering international peacekeeping and how this history has solidified peacemaker and peacekeeping myths into the Canadian psyche. Historically, Canadian foreign policy has been instrumental in constructing the 'imagined' community of Canadians (Ozguc 2011, 39). Thus, by looking at Canadian internationalism, its specific iterations, and how they evoke the peacemaker/peacekeeper myth, I illustrate how peacemaker/peacekeeping myths have been used to construct and reinforce a Canadian identity that reflects White settler society domestically and internationally. Subsequently, I examine the impact of nation-building mythologies on the situatedness/positionality of White settler society and how it influences arrivants' social position as a perpetrator and ally. I look at an example of Canadian foreign policy: Pearsonian internationalism of 1990, which was posited as a natural expression of Canadian identity through invoking myths and narratives that idealize being Canadian. I do this to 1) highlight the interconnectedness between Canada's foreign and domestic political discourses and action, and 2) examine the impact of nation-building mythologies on the situatedness/positionality of White settler society and how it influences the situatedness/positionality of arrivants. I argue that by collectively appropriating and sustaining the narrative of the benevolent peacemaker and peacekeeper, dominantly situated settlers avoid accountability or taking up information that challenges dominantly situated knowers. For arrivants, this perspective means that they are expected to assume the standards and norms set by settlers and take in nationbuilding myths in order to assimilate into mainstream culture and ideology. I argue that 
these factors have shaped and continue to shape relationships (or lack thereof) between Indigenous and non-Indigenous peoples.

\subsubsection{Canada's leadership in international peacekeeping}

In the 1960s, Quebec's nationalism and the rise of immigration from Asia disrupted the Canadian identity that imagined the "Canadian self" as Anglo-Saxon, White, and Christian (Ozguc 2011, 42). Maintaining national unity at this time become a priority, which required a "shift from the exclusion of differences to recognition of them" (42). As a result, the Canadian government began to change its assimilationist rhetoric to one geared towards greater inclusion and diversity. Additionally, economic decline coupled with constitutional debates surrounding the 1995 Quebec Referendum and the failures of the 1987 Meech Lake Accord and of the 1992 Charlottetown Accord had a significant impact on the sense of belonging in Canada (39-40). To remedy rising concerns about national unity and social solidarity, the federal government turned to foreign policy for a particular discursive construction of Canadian identity. As Umut Ozguc puts it, the discourse on internationalism that emerged during this time reinforced "a domestic political culture of peace, negotiation, and compromise" on the international stage (42).

The building of this Canadian identity began before the constitutional debates, as was evident especially under Lester B. Pearson's time as the Secretary of State for External Affairs from 1948 to 1957. Pearson collaborated with the UN to create a peacekeeping force to stabilize the 1952 Suez Crisis. Canadian peacekeeping troops aimed to maintain peace, protect human rights, and restore the rule of law. Pearson's leadership and Canada's role in the UN accelerated the nation-building efforts of the Canadian state in creating national unity in an otherwise "fragile" domestic structure due 
to ethic and regional differences that threatened Canadian unity (Ozguc 2011, 30). During the 1990s, Canada continued to be one of the leading advocates of human-centered policy under its greater human security agenda. This was posited as a "natural expression" of Canadian identity because of Canada's role as peacekeepers and good international citizens (Ozguc 2011, 38). Note that this narrative was further supplemented by notions of "Canadian exceptionalism" (before the Harper government), which distinguished Canada as different and morally superior to the United States on the international stage (Wagner 2006, 47). With a strictly human security agenda, Canadians saw themselves as non-violent and with no economic motives outside of North America (47). As an extension of Pearsonian Internationalism, this image of Canada solidified the benevolent peacekeeper myth as the image of the Canadian self as it became further legitimized on a global scale. Since then, scholars of Canadian foreign policy have argued that such narratives of Canadian identity "have a disciplinary function in that they operate to construct a positive self-image of Canada" (Wagner 2006, 38).

Drawing on these insights, Ozguc suggests that "Canadianness was (re)constructed through the Canadian discourse" in foreign affairs as being tolerant, peaceful, generous, a good international citizen, and non-American (Ozguc 2011, 39). Three main beliefs safeguard Canada's peace-loving, peacekeeping image internationally: 1) it appears that Canadian Forces have historically made peacekeeping their primary mission; 2) it is believed that Canadian peacekeeping "has been motivated largely by altruism and humanitarianism"; and 3) Canadian exceptionalism is what differentiates it from the actions of other, more predatory states like the United States or 
the United Kingdom with clearer and better documented imperial and colonial histories (Wagner 2006, 45-47).

Accordingly, this peacekeeping myth is an important lens through which the public perceives Canada's national interests, but when understood via the three main beliefs outlined above, buying into the myth could not be more ahistorical. On the one hand, this ahistorical narrative persists because it downplays the extent to which Canada's political self-interests are motives behind the peacekeeping missions. Eric Wagner uses Canada's operations in Suez, Vietnam, and Cyprus as case studies to argue that

When engaged in peace operations from 1954 to 1973, Canadian foreign and military policy served the national interest: helping to stop the spread of communism; acting as zealous Western representatives on international bodies; maintaining important geographical areas open for use by the West; and, most prominently, working to maintain unity and cohesion in multilateral organizations important to Western interests, especially NATO. (Wagner 2006, 46)

On the other hand, the peacekeeping myth obscures histories of violence that have been committed by Canadian troops. A documented example of this violence is the Somalia affair.

\subsubsection{Canada's failures as peacekeepers}

The Somalia Affair was a Canadian military scandal that occurred in 1993 when graphic images leaked of the murder of sixteen-year-old Shidane Abukar Arone, who was brutally tortured to death on March $4^{\text {th }}, 1993$, by members of Canadian peacekeeping forces (Canadian Airborne Regiments). The death of this child was revealed to the world 
via graphic photographs of his disfigured head choke-held in place with a baton whilst two Canadian peacekeepers smiled behind him (Razack 2004, 4). Interestingly, it was not until several videos surfaced of human rights violations and soldiers admitting to their racist views of Somali citizens that action was taken to officially disband the Canadian Airborne Regiment. Only then did the violent behavior of these alleged peacekeepers incite national outrage from Canadians, challenging our claims to be agents of peace in global affairs and prompting a public inquiry. It is important to note that the influx of evidence of violence and war crimes did not stop there; but instead, the trophy photos were destroyed so that the violence that occurred on this 'peacekeeping' mission was kept away from the public and the inquiry terminated (142).

Here, Razack notes that the Somalia affair exemplified the connection between racism, violence, and peacekeeping to many Canadians - but that such awareness did not last long. She states,

The connection shook our sensibilities to the core, challenging as it did national claims to a special expertise in peacekeeping, and more importantly, to a history without racism. The flare died, however, as quickly as it was born. Today, despite a national inquiry into the deployment of the troops to Somalia, what most Canadians are likely to associate with peacekeeping is the nation's glorious role as peacekeepers to the world... At most, some would concede that what happened in Somalia was horrible, but they would put it down to a few 'bad apples,' bad generals, and a 'rogue regiment' the latter now happily disbanded. (Razack 2004, 6) 
Razack identifies the role of colonial histories and national mythologies as key components of what enabled peacekeeping violence to occur and to be forgotten. In her account, the national mythologies that are manifestly based on race underlie and are enacted in Canadian peacekeeping. Here, race informs notions that 'we' "know about democracy" and 'they' do not; 'we' have values of peace, order, and civility, while 'they' do not" (Razack 2004, 13). Note how these sentiments of superiority have a striking resemblance to those used by settler-colonizers in the logic of terra nullius, the doctrine of discovery, and in justifying acts of elimination and enforced reform (such as residential schools) of Indigenous people resulting in socio-economic oppression and hermeneutical injustices emerging from these practices. In her account, the 'we' in this context is a White category. Razack argues that racial categories and hierarchies did not just appear in settler societies, but rather, the "European desire for distinct racial classifications meant that Whites needed to constantly (re)create their own identities and superiority against the bodies of racialized Others" (Razack 2002, 49). Consequently, this 'we' refers to a White settler society who not only imagined themselves to be "to be the original citizens" but have also actively oppressed Indigenous people and imposed onto them marginalized citizenship through violence, the imposition of dominant collective interpretative resources, and the systematic and willful ignoring and devaluing of Indigenous collective interpretative resources.

The human security agenda in Canadian foreign policy has been instrumental in constructing the imagined community of Canadians. This chapter adopts the prevailing critical constructivist reading of the political discourse that brought Canadian peacekeeping to the international stage. In Canada, the national mythology of 
peacekeeping has played a role in creating a top-down understanding of Canadian identity for White settler society. In particular, Razack's analysis of the Somalia affair reveals important details of the positionality of White settler society, both domestically and internationally, in creating an image of the 'Canadian' self—-based on their own historical and contemporary peacemaking myths. In this light, our national identity is contingent on relational and political constructions that are reproduced within dominant interpretive resources. To this end, Razack's analyzes the relational construction of 'we' for White settler society that outcasts Indigenous peoples as "dead or dying," while other racialized peoples are considered "recently arrived" (Razack 2002, 13). The Somalia affair demonstrates at the international level how White settler society used the categorical 'we' and narratives stemming from the benevolent peacemaker myths to cast the global south in the role of 'the Other' and to see Canadians' identity as being tolerant, peaceful, generous, and good international citizens.

The racial scripts that are present domestically replicate themselves with our peacekeeping endeavors in Somalia. Razack underscores this point by asking, "when Canadian peacekeepers went to Somalia, who did they think they were and what did they think they were doing in the hot desert of Berlet Huan?” (Razack 2004, 9). We were good people of a middle-power nation with a special responsibility on the world stage to witness and "help to mark out the terrain of what is good and what is evil" (26). To this end, Razack examines the sentiments Canadian soldiers expressed to anthropologist Donna Winslow about their feelings and views of Somalis, who were rightfully apprehensive of their presence in their communities. She summarizes how 'peacekeepers' cited an 'atmosphere of ungratefulness' that Somalis had because of the rocks they would 
throw at the troops and the growing "fantasies shaped from the start by the vitality of the peacekeeper myth and by the strong sense that Canadians were in Africa to save Somalis from themselves" (Razack 2004, 69). She contends that "for Western subjects to feel whole and to understand their presence in that space as necessary and justified, Black savagery had to exist" (69). In relation to the 'savagery' of Somalis, 'we' can bare the skin of civility and benevolence once again. In Somalia, it was our special responsibility to save Somalis from "the excesses of their own tribal society" in what the media purported was a nation of "savages who got ahead of themselves technologically" (68). As covered in Chapter 2, imagining the 'other' in this way is not an unprecedented act by settler society in 'Canada.'

The myth of peacekeeping secures the images of peacefulness at home, created from myths of benevolence, and reinforces the idea of a 'Canadian mosaic' internationally. Peacekeeping is then firmly embedded in the collective interpretive resources of the nation. National peacekeeping myths play an instrumental role in constructing a top-down understanding of Canada and Canadian identity and are largely responsible for ignoring and negating dissenting perspectives. Razack's findings of how the inquiry commissioned by the government failed to adequately recognize how racism informed the peacekeepers' malicious actions also demonstrate this perspective. She notes that although the inquiry "cataloged these events exhaustively" before it was abruptly shut down, it only went as far as recognizing the failures of the Regiment generals; denouncing military leaders inevitably supported the narrative that this was the fault of a few bad (and few specifically White supremacist) 'apples' (Razack 2004, 6). As a result, she argues that the public response to the Final Report failed to further confront 
issues of deep structural and interpersonal racism in Canadian culture, the Canadian forces, and Canadian foreign policy. Instead, the public largely looked past these issues to focus on the bureaucratic failing of the regiment instead of confronting the racist underpinnings as a root cause of the Somalia affair.

This failure to achieve conceptual insight is influenced by the dominant interpretive resources of White settlers who have historically refused to acknowledge the experiences and interpretive resources of the 'other.' Understanding our national identity through these mythologies about the relationships between White settler-colonizers and Indigenous communities (and the early settler-colonial process) reveals the extent to which mythologies of benevolence and peacekeeping have been established and maintained through willful White ignorance and the denial of relationality so much so that it transcends the structured invasion and colonial project of Indigenous peoples on Turtle Island and replicates itself internationally in beliefs about Indigenous peoples of another land. I develop this claim in greater detail in the section that follows. For now, note that White settler society has had the epistemic power to create nation-building mythologies in their desired image.

\subsection{The role of Narrative and Myths in the Case of Arrivants}

As noted in Section 3.1.2, Regan's position as a non-Indigenous White woman in White settler society draws out the history, legacy, power, privilege, and level of complicity that Whiteness possesses in the ongoing project of colonization. Conversely, I belong to the category of arrivants as an immigrant from Bangladesh who had the privilege to settle on North American Indigenous land. Arrivants like myself can similarly apply critical selfreflectiveness to acknowledge the power, privilege, and complicity we hold in Canada's 
social hierarchy. Arrivants are beneficiaries of colonization. As settler-allies, we are subjected to the duality of existing in both a perpetrator and ally space, and the embodiment of this contradiction is often reflected in our "mental, emotional, and material habits" (Regan 2010, 27). This duality is especially necessary because many young arrivants are taught about Canadian history and Canada's global identity through the lens of Canadian exceptionalism and the nation-building myths constructed by White settler-colonizers. $^{14}$

The settler-colonizers' White ignorance, lack of epistemic interdependence with Indigenous communities, and commitment to the settler identity of benevolent peacemaker on global and domestic levels establish the epistemic resources most accessible to arrivants. For arrivants, accepting nation-building narratives, even when personal experiences on this land do not align with this narrative, is common. This acceptance is often because of 1) the pre-established epistemic/hermeneutical dominance of White settler society, 2) how this subsequently influences their epistemic interaction/engagement with White settler-colonizers and White settler history, and 3) the need to assimilate. To this end, Lorenzo Verancini explains that while "Settlers are the founders of the political order and carry their sovereignty with them (on the contrary, migrants can be seen as appellants facing a political order that is already constituted)" (quoted by MacDonald 2020, 6). A part of this order is how White settler-colonizers maintain their (largely mythologized) understanding and experiences of benevolence and ownership of the Canadian landscape as generalizable to the entirety of reality. To this

\footnotetext{
14 "Traveling like a Canadian means you're a beacon of peace in turbulent situations" - Sandra Oh https://www.youtube.com/watch?v=o_8HDmQsMM8
} 
end, a 2016 national poll reveals that $68 \%$ of the 4,000 participants in the poll felt that minorities should do more to assimilate into mainstream (settler-colonial) society (MacDonald 2020, 6).

Mythologies about the history and origin of Canada have provided White settler society with a story of the land that serves the settler-colonial project and gives them a basis from which to define themselves as part of a community by "defining who belongs and who does not belong to the nation" and it establishes the racialized structure of citizenship that characterizes contemporary Canada (Razack 2002, 2-5). Razack explains that our stories of land in narratives (shared and developed by settlers) is, therefore, "manifestly a racial story" (3). The story of the land that was once imagined as empty and developed by enterprising European settlers changed in the 1990s with the arrival of 'third world' refugees and migrants. As we have seen in Chapter 3 this story produces European settler-colonizers as the bearers of civilization while simultaneously trapping Indigenous peoples in an earlier time before civilization and rendering people of color as late arrivals to an already well-developed Canada (3-4). Razack asserts that

if Aboriginal peoples are consigned forever to an earlier space and time, people of color are scripted as late arrivals, coming to the shores of North America long after much of the development has occurred. In this way, slavery, indentureship, and labor exploitation - for example, the Chinese who built the railway or the Sikhs who worked in the lumber industry in nineteenth-century Canada - are all handily forgotten in an official national story of European enterprise. (3) 
Instead, the arrival of people of color changed the geographical imagination through antiimmigration rhetoric that enabled an increased policing of the border and of bodies of color (4).

The arrivant experience and situatedness thus require a spatial and relational understanding of identity, space (land), and how Whites secure their dominance in settler society through their pre-established settler-colonial systems, laws, customs, and the interpretive resources they create. As such, the social position of arrivants is within the pre-established racial/social hierarchy that places White settler society as hermeneutically and socio-politically dominant. This hierarchy puts arrivants at a disadvantage in understanding the Canadian landscape beyond the hermeneutical standards of White settler society. In this way, and especially as it relates to national mythologies, many arrivants become subject to the structure that has already caused gaps in the collective interpretive resources of understanding Canadian identity and history. Consequently, the sensibilities that arrivants have as epistemic agents in the pre-established system of oppression against Indigenous communities affect the specific colonial "mental, emotional, and material habits" (Regan 2010,27) they take on as new settlers.

Additionally, it is important to remember that racialized arrivants may also exist in the context of their own oppression as well as within the systems of ongoing oppression towards Indigenous peoples in Canada. For this reason, their epistemic sensibilities may be very open beyond colonialist perspectives and blind spots to negotiate and challenge the available Canadian myths, narratives, White ignorance, and subsequent hermeneutical gaps. As a non-White arrivant in Canada, Razack writes that part of such an analysis of the arrivant experience is the aim to reveal the racialization 
processes that arrivants experience spatially in Canada. She writes, "When police drop Aboriginal people outside the city limits leaving them to freeze to death, or stop young Black men on the streets or in malls, when the eyes of shop clerks follow bodies of colour, presuming them to be illicit, when workplaces remain relentlessly White in the better paid jobs and fully 'colored' at the lower levels, when affluent areas of the city are all White and poorer areas are mostly of colour, we experience the spatiality of the racial order in which we live" (Razack 2002, 6).

Although beneficiaries of Canada's settler colonialism, many arrivants are also a part of the hermeneutically disadvantaged that is characteristic of their own communities' situatedness in Canada. As a result, they may have a more acute sensitivity to hermeneutical gaps. While this might not be true for every arrivant due to their epistemic interaction with the collective interpretive resources of the nation, they are often better positioned to be attuned to the hermeneutical gaps from their own experiences of oppression. Recall from my discussion of Pohlhaus in Chapter 2, section 2.1.2.1, that this is an insight central to standpoint theory. It is also an insight that I will explore and develop in Chapter 6 in my discussion of possibilities for challenge and change.

Chapter 4 has provided an account of the history and function of ignorance and their manifestation in relationships between and among White people, Indigenous people, and people of colour in Canada. What we need to note from this history is that the dynamic of racial superiority is first present in Canadian society by way of its settlercolonial history that is established by White settler society and through their structured invasion of land and interpretive/conceptual resources. It is then further imagined into a national mythology that allows the nation to, first, forget its bloody/oppressive past and 
present; second, create an identity of the 'we' in terms of mythologies of innocence and benevolence as the national self-image; and third and in the ways that Razack argues, enacting the myths and identity internationally as peacekeeping (and for self-serving interests as identified by Wagner). I have argued that all these factors are an inevitable continuum of Canadian history.

In this chapter, I examined various myths regarding how White settlers perceive themselves domestically and internationally, their historical perception of Indigenous people, the land they colonize, and the impact this has on the interpretive resources that arrivants may take up. I have shown how the benevolent peacekeeper myth and Canadian international peacekeeping are contemporary manifestations of myths that have emerged from early settler-colonial relations in 'Canada.' I argue that for these mythologies to flourish as they have, both domestically and internationally, a cultural refusal to know has been enacted by settler-colonizers to disqualify Indigenous knowers whose experienced ways of being reveal the inadequacy of our current epistemic resources. This is a willful ignorance that is especially relevant to White settler society as those who have imagined themselves to be the original citizens, established the settler-colonial systems, laws, and customs and subsequently oppressed Indigenous people and imposed on them a marginalized position in society. Concerning the 'savagery' of Indigenous people on Turtle Island, 'we,' the good people, the Christians, the wise and benevolent White settlers turned White Canadians, were models of civility and benevolence. In Somalia, Rwanda, and other nations, 'we' perceived 'ourselves' as once again models of civility and benevolence toward the 'other.' In the following chapter, I apply and extend Pohlhaus's and Medina's frameworks from Chapter 2 to the case of willful hermeneutical 
ignorance in such historical and cultural narratives/mythologies and in the unique context of settler-Indigenous relations in Canada. 


\section{Chapter 5: An Epistemology of Ignorance and Settler-Colonial Oppression in Canada}

Recall in Chapter 2, sections 2.1.1 - 2.2.1, where I introduced the work of Pohlhaus and Medina to highlight how positionality and relationality are crucial in instigating and sustaining hermeneutical injustice caused by willful ignorance. Using these elements of one's position and relation to others, Pohlhaus and Medina depart from Fricker's more rigid account of hermeneutical injustice to consider the relational aspects of epistemic injustice through the theses of willful hermeneutical ignorance and communicative interactionism, respectively. Pohlhaus and Medina highlight how Fricker's account: 1) does not bring to light how marginalized knower's can resist epistemic domination, be hermeneutically sensitive to dominant interpretive resources, and produce counterinterpretations of their experiences; 2) fails to acknowledge how sometimes, dominantly situated knowers ${ }^{15}$ often willfully dismiss this fact; and 3) according to Pohlhaus, ignores how the 'dialectical relationship' of one's situatedness/positionality and interdependence/relationality with one another determines what we are likely to know.

Chapters 3 and 4 proceeded by unpacking the history and positionality of early Europeans on Turtle Island as dominantly situated colonizers and of how this relationship continues to eliminate, displace, and marginalize Indigenous peoples and their collective interpretive resources through myths of Canadians as benevolent and as peacemakers/peacekeepers. Through a discussion of Koggel's account of hermeneutical injustice in Chapter 1 and an historical account of settler colonialism in Chapter 2, I start to explore how, as marginalized knowers, Indigenous people can not only achieve

\footnotetext{
${ }^{15}$ Fricker would also refer to dominantly situated knows as the 'hermeneutically powerful'.
} 
conceptual insight into their experience despite facing hermeneutical erasure and elimination, they also resist epistemic domination, become hermeneutically sensitive to dominant interpretive resources, and produce counter-interpretations of their experiences that they routinely offer as conceptual resources. My investigation of the colonial history, legal legacies, and myths in Chapters 3 and 4 substantiates/adds to Koggel's analysis of fundamental asymmetries of power that are sustained by the epistemic exclusion of, and domination over, Indigenous communities by settler society over who gets to "tell the stories" also means that "how the stories are told shapes our collective history" (Koggel 2018, 242).

In this chapter, I go beyond Pohlhaus's and Medina's work on the topic of willful hermeneutical ignorance and communitive interactionism by using and extending their insights on hermeneutical injustice and applying it to the case and context of settlerIndigenous relations in Canada. I show that White settlers-colonizers have the power and privilege to willfully refuse and disqualify Indigenous knowers as equal and valid epistemic agents. The version of communicative interactionism I defend in this chapter builds on Medina's insights to carry out a pluralistic analysis of how settler colonizers and arrivants have poor communicative dynamics that deny relationality and epistemic interdependence with the Indigenous knowers by way of willful White ignorance that is enacted and performed in these relationship dynamics. To build my argument in section 5.1-5.3.1, I look at 1) the colonizer-colonized relationship between White settler society and Indigenous communities to reveal communicative dynamics that deny relationality and epistemic interdependence with the Indigenous knowers, 2) the performative and interactive role settler colonizers have in perpetuating hermeneutical gaps, and 3) the role 
of systemic distortion in the dominant Canadian collective interpretative resources. More specifically, in section 5.3, section 5.3.1 I look at how hermeneutical gaps are caused relationally, revealing issues such as systemic distortion for Indigenous communities, how systemic distortion might affect the collective interpretive resources available to all, and how settlers are responsible for perpetuating such distortions. Lastly, in section 5.4, I argue that settlers have a unique hermeneutical responsibility in our relationships with Indigenous communities that call for taking responsibility for impoverished communicative and interpretative habits.

\subsection{Denying Relationality and Willful White Ignorance}

In Chapter 2, I discussed White ignorance as a type of ignorance exercised by White (and non-White) people where they are unable to be aware of their own racial identity and the presuppositions and consequences of their racial positionality. Pohlhaus and Medina develop their arguments for willful ignorance and communicative interactionism through the examination of White ignorance. Recall from Chapter 2, section 2.2.1 that what is meant by White ignorance can be informed through Charles Mills's account in The Racial Contract (1997).

Mills argues that White people have become unable to understand the world that they have created and that patterns of "localized and global" cognitive pathologies produce this outcome (Mills 1997,18). He writes, "in effect, on matters related to race, the Racial Contract prescribes for its signatories an inverted epistemology, an epistemology of ignorance, a particular pattern of localized and global cognitive dysfunctions (which are psychologically and socially/functionally), producing the ironic outcome that Whites will, in general, be unable to understand the world they themselves 
have made" (18). In the Canadian context, how do "localized and global cognitive dysfunctions" occur? The role of White ignorance is significant here. The situatedness of White settler society is shaped by their race and a complex history of White settler colonization that positions them as privileged and dominantly situated individuals with material and hermeneutical power. White settler society's experience on Turtle Island and how that is also projected internationally involves a carefully cultivated racial blindness of the White gaze that constructs a mythological account of the Canadian self and Canada's history by not taking non-White experiences of the world as salient, and more deeply, by not seeing non-White people as fully equal epistemic agents.

The result of this situatedness can be seen in how White settler society can assert their positions of privilege and power through the dominant collective interpretive resources by maintaining ignorance to the ways in which the world is revealed to Indigenous people on Turtle Island, or to Somalis in Somalia, for example. The Canadian settler identity of benevolence and peacekeeping is thus strategically based on mythologies that have been constructed via White ignorance (and resulting racial blindness to the epistemic resources from the margins) to situate White people and Whiteness as superior in relation to Indigenous populations. Applying Pohlhaus's insights from Chapter 2, section 2.1.2.1, White settler society's racial blindness also reflects their dual failure to understand their own social position and be epistemically interdependent with Indigenous people as equal epistemic agents. As this colonizercolonized relationship emerges from an insensitive racist mindset/epistemic framework, there is a lack of genuine and robust epistemic interdependence for White settler-colonial knowers with Indigenous knowers. For example, I argue that when we see issues such as 
Canada's forced assimilation of Indigenous children through Residential schools as a way of managing the "Indian Problem," to "killing the Indian in the child" we are also seeing instances of a paternalism and 'benevolence' that requires a strategic denial of relationality in order to carry out policies on behalf of a community which is so harmful to them (Koggel 2018, 244).

In "Denying Relationality: Epistemology and Ethics and Ignorance," Sarah Hoagland asserts that "relationality involves our forming and being formed, both individually and culturally, in relation through our engagements and practices" (Hoagland 2007, 99). In the Canadian context of the colonizer-colonized relationship, engagement refers to the practices of erasure, elimination, and othering. Hoagland also argues that ignorance strategically involves the denial of relationality by practitioners of the dominant culture who are ignorant about those whom they oppress (96-97). What she highlights in this analysis is that "epistemologies that presuppose autonomy make relationality that structures subjectivities invisible" and recognizing that relationality means acknowledging ontological interdependence (Sullivan and Tuana 2007, 5). By applying this view, we can start to question the ontological notion of the independence of a nation that sees itself as benevolent peacemakers towards the Indigenous peoples they oppress. I argue that for settler-colonizers to have a sense of benevolence requires a strategic denial of relationality and thus a denial of epistemic interdependence with Indigenous people as equal epistemic agents. Those who hold and assume dominant collective interpretative resources are 'independent' in the sense that the collective interpretative resources of the oppressed and marginalized are perceived as not needed to make sense of their world. 
While Medina's and Pohlhaus's approaches may differ in the results of their analyses, I take their methods as applicable to the Canadian context, as they offer a good starting point to investigate how White settler society can choose not to know the world of the marginalized both domestically and internationally in a way that marginalized Indigenous people cannot choose. Willful hermeneutical ignorance and communicative interactionism are concepts that make sense of the power that dominantly situated knowers have in relation to marginalized knowers in the context of a socially stratified society. Moreover, this power dynamic informs and affects the communication between and among groups. The account of willful hermeneutical ignorance I am developing in the context of the settler-Indigenous and arrivant relationships fits with Pohlhaus's account of willful hermeneutical ignorance. The victims of willful hermeneutical ignorance in my analysis are not merely hermeneutically dispossessed subjects. Rather, they are people with ample interpretive resources but are simply not being heard or understood because of settlers' willful hermeneutical ignorance. Because settlercolonizers' dominant collective interpretive resources are sustained by willful White ignorance, they are perpetrators of hermeneutical injustice, and they are also victims of hermeneutical disadvantages in the sense of a failure to know.

Throughout Canada's history, settler-colonizers have not listened; instead, they have silenced and hermeneutically disrespected Indigenous peoples to the point where an objective perspective of Canadian history, politics, and society is virtually impossible. Building on these concepts in Canada's settler-colonial context, I have drawn the following conclusions: 1) settler-colonizers can wield the power of their social position in and through their White ignorance and denial of interdependence with Indigenous people 
in order to disregard epistemic resources beyond their purview, and 2) we can start to understand how settler-colonizers are emboldened to ignore the experiences and resources of Indigenous peoples by looking at how their testimonial and hermeneutical insensitivities are performed agentially. An important point made in Chapter 2, section 2.2.1, and repeated here is that because hermeneutical injustice is performed relationally, settler-colonizers are not inherently incapable of learning the epistemic resources of marginalized knowers. Their ignorance and lack of epistemic relationality with indigenous peoples is not predestined or fixed for all time. Instead, it is willfully enacted and maintained. White settler-colonizers or arrivants can, and many do, learn to have a more objective perspective of the world when they learn to use the epistemic resources of the marginally situated. Such learning can occur once they stop pre-emptively dismissing and refusing to listen to, or acknowledge, the epistemic resources of the marginally situated person and once they recognize that the fundamental asymmetries of power between the colonized and colonizer in 'Canada' are the result of a willful hermeneutical ignorance on the part of the colonizer.

\subsection{Relational Aspects of Communicative Interactionism and Willful}

\section{Hermeneutical Ignorance}

I take from Medina an understanding that "we need to follow communicative exchanges long enough in order to detect their patterns of epistemic interaction and the communicative dynamics that unfolds in them over time" $(2012,203)$. Accordingly, thus far my analysis of the asymmetries of power that are sustained by the epistemic exclusion of, and domination over, Indigenous communities via structural colonialism, capitalism, and nation-building mythologies/strategies have detailed an inverted settler epistemology 
shaped by White ignorance that produces a uniquely Canadian pattern of local, national, and global cognitive dysfunctions. Communicative interactionism applied in this context can also reveal the various dynamics through which Indigenous voices revealing their racialized experiences to White settler society are silenced, constrained, minimized, or seen as unimportant. Here, testimonial injustice and hermeneutical injustice are not neatly delineated; instead, each support and sustain the effects of the other.

Medina explains that hermeneutical injustices are maintained and passed on through testimonial dynamics that "exhibit systematic failures of communicative and performative responsiveness: interpretative gaps among communication partners are formed, maintained, and passed on because those who are struggling to make sense are persistently not heard and their inchoate attempts at generating new meanings are blocked or unanswered" $(2012,206)$. Recall from Chapter 2 that Medina's thesis of communicative interactionism can be summarized in the following way:

MP1. There are communicative/testimonial dynamics that can be silencing, constricting, excluding, and/or otherwise minimizing to certain voices. (203-206) MP2. These dynamics are a result of individuals and groups failing to be reciprocally responsive, open, or sensitive to each other. (207-211) MP3. Individuals and groups have an interactive and performative responsibility to be responsive, open, and sensitive to each other through the "speech acts" of their daily lives so that we may "take responsibility for how our communicative agency relates to the blind-spots of our social practices" (216). Doing so would mean that one is being hermeneutically sensitive. 
MP4. Poor communitive/testimonial dynamics between individuals and groups (characterized by a lack of responsiveness, openness, and sensitivity) will result in hermeneutical insensitivities that further maintain the presence of hermeneutical gaps among the individuals and groups involved.

MP5. Hermeneutical gaps must be understood in terms of failed communicative/testimonial dynamics because it uncovers the relational contexts which tell us important information on "who is communicating (or trying to communicate) what to whom" (207).

I now argue that Medina's thesis of communicative interactionism can be expanded by adding it to my account of willful hermeneutical injustice in the settler-Indigenous and arrivant context in Canada. This account adds a relational and context-specific analysis of the role of differently situated settler-colonizers and arrivants and can explain the specific epistemic harms to particular Indigenous communities. Not only that, but I also argue that understanding that there are communicative dynamics in and through which different Indigenous communities on Turtle Island are differentially silenced pre-emptively is the key to understanding hermeneutical injustices in 'Canada.'

At this point, I shift my structural analysis of willful hermeneutical ignorance to the social interactions that take place in Canada's complex and diverse pluralistic communities that cause epistemic harms through ignorance and pre-emptive dismissals in practices of distrust, bad remembering, and bad epistemic habits. The version of communicative interactionism I defend in this thesis recognizes hermeneutical injustice as the kind of injustice shaped by performed communicative dynamics by the powerful that deny relationality and epistemic interdependence with the marginalized by way of 
willful White ignorance that manifests foundationally, structurally, and agentially and has the effects of a pre-emptive silencing of Indigenous people (as well as bad remembering of the past and normalized bad epistemic habits, which will be covered in Chapter 6).

\subsection{Pre-emptive Dismissal, Silencing and the Fragility of Communication}

Fricker was insufficiently precise in characterizing hermeneutical injustice as purely structural and in taking testimonial and hermeneutical injustices as different in when and how they occur. Recall that an investigation of the relationship between dominantly situated knowers and marginally situated knowers by Medina and Pohlhaus quickly reveals that hermeneutical injustice happens in relationships at all levels, dissipating the boundaries of testimonial injustice and hermeneutical injustice overall. Fricker offers a limited account of silencing that leads to epistemic injustice. For Fricker, one type of silencing is pre-emptive testimonial injustice, whereby the speaker is automatically assigned a deflated amount of credibility simply due to some identity prejudice (Fricker 2007, 130). Fricker considers pre-emptive silencing of this nature a structural injustice, which is a subtype of testimonial injustice (130). The second type of silencing she considers is when one is used as merely an informant for the dominantly situated knowers from which to gain knowledge. In such cases, rather than allowing the informant to be an epistemic agent sharing knowledge, she is undermined in her capacity as a giver of knowledge and rendered as only a source of information (132). This is what Fricker calls epistemic objectification. Here, Medina's contextual analysis of preemptive silencing can also reveal that certain communicative dynamics may not exclude any particular group from participating, but rather, the voices of different members from different groups may be heard less or differently. By using a contextual approach, Medina looks for the 
specific communicative interactions that silence or constrain the participation of specific groups of people from influencing the dominant collective interpretative resources. He argues when some people's epistemic agency is limited or undermined, it is "at the service of the inquirer's question, assessment and interpretations" (Medina 2012, 204).

Here, Medina offers a more detailed account of how we communicate in relation to one another in ways that reveal patterns of silence that are part of both epistemic injustice and — especially—of hermeneutical injustice (Medina 2012, 202-206). For Medina, silencing is not just an epistemic consideration as it is for Fricker but also a communicative one. More specifically, Medina highlights how reciprocity and reversibility are central components of communication that, when breached, lead to silencing. He states,

Silencing is one of the areas in which we cannot separate out communicative and epistemic agency: it is because of impoverished communicative dynamics without reciprocity and uptake that epistemic trust cannot be established, and credibility is undermined; and when epistemic subjectivity and agency are seriously compromised, the subject's communicative capacities cannot be recovered and she will enjoy, at best, an inferior voice in the interaction. (Medina 2012, 206) Medina is suggesting that there is a strong performative and interactive component to hermeneutical injustice: that we can silence others in and through the ways we might fail to listen to them.

I argue that understanding that there are communicative dynamics in and through which different Indigenous communities on Turtle Island are differentially silenced pre- 
emptively is the key to understanding hermeneutical injustices in Canada. Crucially, this analysis of silence breaks down stricter distinctions of testimonial injustice and hermeneutical injustice and locates settlers as "co-perpetrators" of hermeneutical injustice (with or without their knowledge or intention). We see that hermeneutical injustice is sustained by testimonial interactions that fail at being fair in the uptake of what is being said by Indigenous people about their history and experiences. Borrowing from Jill Stauffer, Koggel identifies the effects of such testimonial insensitivities that Indigenous people face in Canada as ethical loneliness (Koggel 2018, 251). In Ethical Loneliness: The Injustice of Not Being Heard (2015), Stauffer explains ethical loneliness as the harm that survivors of unjust treatment experience when people do not care to hear their stories, and the institutions specifically designed to hear their testimonies, unfortunately, and ironically fail to listen. Stauffer defines this as "the experience of having been abandoned by humanity compounded by the experience of not being heard" (Stauffer 2015, 1).

As part of her analysis of relationships between colonizers and the colonized, Koggel recognizes ethical loneliness as moral and political abandonment (Koggel 2018, 251). In terms of one of my central arguments, this abandonment is a consequence of the settlers' commitment to mythologies and willful ignorance towards Indigenous people. A settler mindset and epistemology that reflect mythologies of benevolence and peacekeeping has resulted in settlers erasing, pre-emptively silencing, and subsequently marginalizing Indigenous collective interpretative resources via bad remembering and bad epistemic habits. I have covered how early colonial White supremacist ideals maintained in and through White ignorance (about myths about land, the 'savages,' and 
the 'benevolent' colonizers) have played a crucial role in erasing, dismissing, and silencing Indigenous people's history and interpretive resources.

One significant example of this erasure is how Indigenous interpretive resources of land protection and environmental stewardship have been silenced. Over time, the structured invasion of Indigenous land, the dispossession of Indigenous land, and the elimination of Indigenous peoples by settler-colonizers in favor of European land ownership, privatization, technical land cultivation, and capitalist modes of resource extraction and profit have effectively silenced and marginalized non-capitalist, Indigenous modes of production and engagement with land. Consequently, this dichotomy creates hermeneutical gaps that render Indigenous voices "less intelligible (and hence less credible) than others on certain matters, and their attempts to articulate certain meanings are systematically regarded as nonsensical" (Medina 2012, 206). This outcome is a structural and foundational pre-emptive silencing that is then further sustained by settler-colonial and arrivant individuals and groups failing to be reciprocally responsive, open, or trusting of Indigenous voices regarding their land rights. As such, gaps in the dominant collective interpretive resources between Indigenous and nonIndigenous communities are beyond ignorance; it is structurally maintained through the pre-emptive dismissal and exclusion of Indigenous communities (Koggel 2018, 240-251).

Returning to the example of the James Bay Hydroelectric dam project and the "1492 Land Back Lane" movement discussed in Chapter 2, I can now add that communicative dynamics between settler-colonizers and Indigenous peoples are silencing and constricting for Indigenous voices. In particular, the James Bay project demonstrates how even though the Cree and Inuit participated in negotiations over the project, there 
was a certain level of hermeneutical insensitivity by developers and members of the Quebec government. Returning to the example of these communicative dynamics highlights the probable lack of responsiveness, openness, and sensitivity from government officials that have the interactive and performative responsibility of working through their blind spots when Indigenous people bring their interpretive resources forward. Note, again, in the communicative dynamic between government officials and the Cree and Inuit, what is exhibited is beyond ignorance; it is a willful dismissal of Indigenous interpretative resources by failing to be reciprocally responsive, open, or sensitive to Indigenous voices regarding their land rights. This conclusion can explain why Canada has not had a very inclusive history when it comes to accepting or taking the testimonies of Indigenous peoples seriously, as it first requires Indigenous people to gain epistemic authority and recognition in a legal system created by settlers (Campbell 2014, 204).

Poor communitive dynamics dissipate the distinctions between testimonial injustice and hermeneutical insensitivities between setter-colonizers and the Cree and Inuit, and they entrench and maintain the presence of gaps in the dominant collective interpretive resources in the precedent-setting land settlement case. In land claim cases in Canada, Dara Culhane points out that when Indigenous people "say today that they have had to go to court to prove they exist, they are speaking not just poetically, but also literally" (originally quoted in Razack 2002, 3). Alternatively, when providing official testimonies of their experiences of Indian residential schools, many survivors have, and continue to be invalidated, silenced, and spoken over. Note that this silencing continues to be the case even in the wake of finding thousands of Indigenous children buried in 
unmarked residential school graveyards just this summer. For example, on July $10^{\text {th }}$, 2021, Winnipeg Catholic priest Rheal Forest gave a sermon in which he accused residential school survivors of lying about sexual abuse to order to receive settlement money, joked about shooting those who wrote graffiti on church buildings, and blamed the media for circulating 'fake news' about Indigenous peoples' experiences in residential schools (Allen, 2021).

Nonetheless, I want to emphasize that settler-colonizers or arrivants can, and many do, learn to have a more objective and factual perspective of the world when they learn to use epistemic resources of the marginally situated once they stop pre-emptively dismissing and refusing to listen to or acknowledge the epistemic resources of Indigenous peoples and shift the fundamental asymmetries of power between the colonized and colonizer in 'Canada.'

\subsubsection{Systemic distortion and interpretive resources within Indigenous communities}

My account of hermeneutical injustice differs from Fricker's because I recognize that hermeneutical gaps in Canadian society have a greater agential factor rather than being merely a consequence of Indigenous peoples facing "a lacuna where the name of a distinctive social experience should be" (Fricker 2007, 150-151). Recall from Chapter 2, section 2.1.1, Fricker's working assumption for hermeneutical injustice renders the experiences of the marginally situated knower in terms of a lack of intelligibility to oneself and to others. While this effect may very well be true in some instances, I argue that the unintelligibility of the experiences of Indigenous people and their perspectives is also largely due to the silencing, what Medina calls the hermeneutical incapacity, of settlers. He states that hermeneutical incapacity is "when the interlocutors are unmoved 
or unable to identify what is being talked about - and, on the other hand, when speakers encounter counter-interpretations that systematically distort their communicative attempts" (Medina 2012, 101). I argue that Canada's assimilationist history, acts of elimination towards Indigenous people, nation-building myths, and the overall collective interpretive resources that reflect and center White settler society are the counterinterpretations that systematically distort Indigenous peoples' communicative attempts and have created a "systemic distortion" that limit some Indigenous people's capacity to understand their own or their communities' experiences under some conditions (74).

Nonetheless, this is not true of the whole social body of Indigenous people and communities on Turtle Island. Take, for example, the recent testimonial interaction between Alan Lagimodiere (Metis), Manitoba’s newly appointed Indigenous Reconciliation and Northern Affairs Minister, and Wab Kinew (Ojibwe), Manitoba's NDP Leader and son of a residential school survivor. On July $15^{\text {th }}$, Alan Lagimodiere, only hours after being sworn in as the Indigenous Reconciliation and Northern Affairs Minister, stated that "from my knowledge of it, the residential school system was designed to take Indigenous children and give them the skills and abilities they would need to fit into society as it moved forward" (Petz 2021). He was swiftly corrected by Wab Kinew (Ojibwe), who responded that he could not accept Lagimodiere's comments and that "it was the expressed intent of residential schools to kill the Indian in the child it is not cultural relativism, it is not revisionist history for us to state that was wrong" (Unger, 2021). This event was followed by the public, including Indigenous leaders such as Grand Chief Jerry Daniels of the Southern Chiefs' Organization (SCO), and Grand Chief Garrison Settee of Manitoba Keewatinowi Okimakanak, condemning 
Lagimodiere's comments (Unger 2021). Clearly, we see that hermeneutical gaps in Canada are not merely about Indigenous experiences that are unintelligible for all Indigenous people equally and in every communicative interaction. Chapters 2 and 3 have shown that the messaging that Lagimodiere endorsed as the Indigenous Reconciliation and Northern Affairs Minister has been the historical precedent of people in power in Canada; thus, it is reasonable to see his comments as a result of deep systemic distortions of survivors' experiences of residential schools, and ultimately, I argue that it is the hermeneutical insensitivity and incapacity of settlers that has shaped such distortions into our collective understandings of Canadian history. Such distortions are the result of settler-colonizers' failure to recognize their own racial identity and the racial blindness and consequences of one's racial positionality and communicative interactions which rely on bad remembering that has failed to uphold Indigenous perspectives.

\subsection{Hermeneutical Responsibility and Creating New Interpretive tools}

As Pohlhaus noted, the upshot of revealing willful ignorance in the dialectical relationship between our situatedness and epistemic interdependence with others is creating "a vocabulary of accountability for what one does not know" (Pohlhaus 2012, 716). Doing so achieves two important goals in my account of willful hermeneutical ignorance in Canada: 1) it "articulates the importance" of knowing one's situatedness, privilege, complicity, and relationship to the settler-colonial project in Canadian society, and 2) it gives us an opportunity to come to know the limits of our own epistemic resources so that we may start to alleviate epistemic tensions and fill in hermeneutical gaps (733). Likewise, Medina argues that there is a shared duty for communities to 
facilitate others' ability "to participate in meaning-making and meaning-expressing practices (Medina 2012,215). This duty entails that we all have specific hermeneutical responsibilities in the relationships in which we communicate with each other. More specifically, he argues that in our everyday communicative interactions, we are required to take responsibility for "impoverished communicative and interpretative habits, no matter how well-entrenched, unconscious and inescapably socially produced those habits may be" (Medina 2012, 271).

Pohlhaus's emphasis on accountability and Medina's emphasis on correcting the communicative dynamic between dominantly situated and marginally situated knowers introduces an agential approach that I apply in my account. I argue that the failure of settlers to uphold hermeneutical responsibilities in the Canadian settler-colonial context amounts to a complicity that is central in creating hermeneutical gaps that cause the epistemic oppression of Indigenous peoples on Turtle Island. I place emphasis on the performative and interactive role agents play in the communicative dynamic between settler-colonizers and arrivants towards Indigenous communities by revealing and centering all settlers' roles in sustaining willful hermeneutical injustice and our responsibility to 1) recognize the limits of our collective interpretative resources and 2) transform the collective interpretative resources available by creating new interpretive tools and acknowledging already developed epistemic resources for knowing the world by Indigenous communities.

In Chapter 6, I first expand on both Pohlhaus's and Medina's framework by looking at everyday communicative interactions where settlers can fulfill or fail to fulfil their hermeneutical responsibilities in their bad remembering of the past and their 
normalized bad epistemic habits. I argue that a deep and radical practice of methodologies that have a relational focus will orient us towards addressing epistemic injustices and relationships of oppression between Indigenous communities and settler populations in (at least) two ways: 1) by enabling agential and collective recognition of hermeneutical injustice, our role in sustaining it, and our responsibility to counteract it; and 2) with this recognition, enabling us to transform our collective interpretative resources so that we are collectively equipped with the knowledge required to achieve and sustain epistemic justice. 


\section{Chapter 6: Corrective Methodological Responses to Willful}

\section{Hermeneutical Ignorance}

In my thesis so far, I have built on Koggel's insights in each chapter to argue that willful hermeneutical ignorance, when merged with Medina's communicative interactionism, presents us with the most appropriate entry point to analyze how epistemic injustice persists between settlers and Indigenous people. In doing so, I developed and expanded Pohlhaus's and Medina's relational approaches to capture specific strategies and characteristics of the willful ignorance that settler-colonizers perpetrate in their denial and ignorance of the legitimacy of Indigenous epistemic resources. In this chapter, I turn to theorizing about how best to approach correcting the interactive and performative aspects of willful hermeneutical ignorance entrenched in a settler-colonial history that has shaped networks of relationships. I draw on the work of Sue Campbell, Christine Koggel, Ami Harbin, and Laurence Thomas to put together a methodological approach that I think can help renew and rebuild relationships between Indigenous communities and settler populations in (at least) two ways: 1) by enabling agential and collective recognition of hermeneutical insensitivities and injustice, our role in sustaining it, and our responsibility to counteract it; and 2) with this recognition, enabling us to transform our dominant interpretative resources so that we are collectively equipped with the knowledge required to achieve and sustain epistemic justice.

In section 6.1, I start by further drawing out the link between memory and responsibility and why settler-colonizers and arrivants ought to remember the past more faithfully and how the past affects their positionality beyond narrow colonial myths. I draw on the work of Campbell and Koggel to outline how good/relational remembering 
can help settlers achieve their unique hermeneutical responsibilities. In section 6.2, I turn to Harbin's account of disorientation and the kinds of disorientation that can be morally beneficial in the settler-colonial context. I then turn to Laurence Thomas's account of moral deference in section 6.3 as yet another methodological response that can be applied in the settler-colonial context. I end the chapter by sketching in section 6.4 the unique performative and interactive role arrivants have in their capacity to resist hermeneutical gaps and/or become perpetrators.

\subsection{Remembering, Responsibility, and Reconciliation}

My discussion of myths in Canada has been an important step in tracing how our memories of the past have shaped settlers' positionality and relationship to Indigenous communities. I have argued that a kind of willful hermeneutical ignorance has emerged as a consequence of remembering Canada's past through early settler-colonial sentiments, structures, and power-dynamics. Sue Campbell's work on memory offers important insights here, especially in cases of public remembering in the context of the historic harms such as Indian Residential Schools in Canada. In Our Faithfulness to the Past: Essays on the Ethics and Politics of Memory, Campbell rejects the conventional views of memory as "archival" and merely stored away and ready for future recollection. She also challenges aspects of the reconstructivist accounts of memory that are skeptical of the role of suggestibility or social influence on memories (Koggel 2014, 494). Campbell argues that social influences on memory have been taken to be a reason to distrust memory, but they have also been the basis for distrusting marginalized groups' experiences of oppression (Campbell 2014, 141). In response, Campbell develops a view of remembering that is relational and focused on drawing out the ethics and politics of 
memory. This focus reframes the discourse of memory from merely a "psychological phenomena of individual or personal memory" to one that recognizes the aspects of memory that are co-determined and informed in social activities and social institutions (xiii). As noted in the introduction of her book, dominant accounts of memory "threaten to obscure the distinction between memory and history, and to leave talk of memory in the realm of metaphor" (xiii).

In her account, Campbell moves beyond focusing on how social interactions can affect the accuracy of memory (especially in contexts in which memories of harm are shared) to argue that remembering can be personal, embodied, and material in and through memory activities that bring forward the significance of the past into the present (Campbell 2014, 27). Memory activities can be reflections about the past, sharing stories of the past, giving testimonies of the past, and preserving our heritage and cultural practices. Memory activities also happen through institutional practices via reparations and truth commissions (xiii). As such, Campbell's account of good remembering 1) centers values such as faithfulness, accuracy, integrity, and responsibility, and argues that memory is a shared act of remembering in relational contexts, and 2) is done through a variety of memory activities in which both the oppressed and oppressor have been “shaped by relationships of inequality and oppression” (Koggel 2014, 500).

In contrast, Koggel explains how bad remembering is "often tied to dominant beliefs about what those without power are taken to remember (badly) about their experiences of oppression" (498). Note that in outlining mythologies about the history and origin of Canada in chapters 2 and 3, I have argued that willful hermeneutical ignorance has emerged because of a bad remembering of Canada's past as reflected in 
and through early settler-colonial structures, othering sentiments, and power dynamics. In terms of my argument thus far, this bad remembering reflects a willful dismissal or refusal of the collective interpretive resources of Indigenous peoples, whose memories and experiences do not align with dominant narratives. The version of communicative interactionism I defend thus includes bad remembering and distrust of Indigenous knowers because of the denial of relationality and epistemic interdependence that settlers have cultivated. Recall in Chapter 4 that I presented this argument by outlining how commitments to the benevolent peacemaker myth have also been preserved as a social memory of benevolence through the dual process of willfully ignoring the experiences of Indigenous communities that challenge the narrative and through a denial of their relationality with Indigenous peoples as epistemic agents. There, I argue that White ignorance and the interpretive resources that it produces/supports (i.e., nation-building myths that have portrayed Indigenous peoples and their cultures as frozen) create hermeneutical limitations on who can successfully share memory with whom and the responsibilities of those with whom memory is shared-especially with respect to memories of harm.

In communicative interactions, how settlers respond to Indigenous peoples' memories of harms will not only impact how and what settlers remember but also their overall ability to participate in alleviating epistemic tensions and filling in their hermeneutical gaps. I have noted how the public remembering of the past often dismisses and discredits how Indigenous communities remember and experience the historical harms to this day. Priest Rheal Forest did this explicitly when he led his congregation by contesting what survivors have been sharing about their memories of the Indian 
Residential schools for years as 'fake news.' Additionally, recall that the Indian Residential schools directly targeted children and attempted to destroy their ability to remember and partake in memory activities that would preserve intergenerational teachings that could sustain their communities (Campbell 2014, 101). Chapter 3 outlined some of the ways this intention was carried out (such as routine punishment for children who communicated in their mother tongue). To this end, Hayter Read, an official from the Department of Indian Affairs, stated that "every effort should be directed against anything calculated to keep fresh in the memories of children habits and associations which it is one of the main objects of industrial institutions to obliterate" (Originally quoted by Campbell 2014, 101). In the contemporary context, we see bad remembering going on in schools' curricula across Canada that often treat Indigenous history as an afterthought ${ }^{16}$ or incorrectly represent ${ }^{17}$ it when it is taught.

Rather than cultivating a collective understanding of Turtle Island, its Indigenous communities, Indigenous perspectives, and the overall history of settler-colonialism on this land, non-Indigenous people have instead centered a story that installs White settler society's claim to land and entrenches hermeneutical dominance through legal fictions, nation-building mythologies, and a cultural refusal to know and engage better. The refusal to acknowledge, embrace, and collectively allow uptake of Indigenous peoples' memories of past harms and their current effects demonstrates yet another aspect of how settler-colonial relationships of power still impede the ability of a more robust settler

\footnotetext{
${ }^{16}$ Ontario Education Ministry cancels curriculum updates on Indigenous history: https://www.cbc.ca/news/canada/toronto/ontario-education-truth-and-reconciliation-commission-trc1.4739297

${ }^{17}$ Alberta's K-6 social studies curriculum: https://www.660citynews.com/2021/03/31/alberta-curriculumunder-fire-for-Whitewashing-canadas-history/
} 
interdependence with Indigenous individuals and communities as epistemic agents. As such, I argue that settlers can first start to fulfill their hermeneutical responsibilities by correcting their bad remembering of the past in order to recognize the limits of the dominant interpretative resources. As Campbell puts it, "memory should be faithful to the past.... To learn is to understand from a position of present need and through what else we have come to know. It is to re-experience our past selectively, as shaped by the demand of an always new present, through the determinations of a history that itself shifts in significance. And of course, we remember with and in response to other people and their needs and histories" (Campbell 2014, 2). In moving forward with the TRC's calls to action to repair historical harms and advance reconciliation, good/relational remembering can help better understand the harm of past injustices and how their legacies continue to shape settler-Indigenous relationships and sustain the hermeneutical and material marginalization of Indigenous peoples.

In chapters 3 and 4, I outlined how settler-colonial history in Canada positions White settler society as hermeneutically dominant in relation to the Indigenous 'other.' I also advanced the argument that hermeneutical gaps in the Canadian context are a result of White settler society creating and controlling the dominant collective interpretive resources by way of structurally and agentially ignoring, dismissing, and marginalizing Indigenous peoples. In Chapter 5, I argued that we could start to understand how settlercolonizers and arrivants are emboldened to ignore the experiences and resources of Indigenous peoples by looking at how their testimonial and hermeneutical insensitivities have a performative and interactive component. In this part of my investigation of the epistemic relationship between settlers and Indigenous communities, I discussed settler- 
colonizers and arrivants as co-perpetrators of epistemic injustice because of the way hermeneutical injustices are sustained by testimonial interactions that fail at being fair in the uptake of what is being said by Indigenous people about their history and experiences. In doing so, my intention has been to pinpoint the unique ways in which settler-colonizers and arrivants are implicated in the hermeneutical marginalization of Indigenous communities.

I now start the discussion of how settler-colonizers and arrivants can begin to take responsibility to hear, learn, and re-understand themselves with respect to Indigenous perspectives, memories, and histories. I put forward two claims: 1) through communicative interactionism and willful hermeneutical ignorance, settlers are accountable for what they do not know, and 2) all settlers can transform dominant interpretative resources by creating new interpretive tools and acknowledging the already developed interpretative resources for knowing the world by Indigenous communities. Note that my focus on accountability here is not centered on placing the same kind of blame on settler-colonizers and arrivants for their hermeneutical insensitivities but to highlight their collective responsibility to do something about it ${ }^{18}$.

My focus is on highlighting how all settlers need to start taking on their hermeneutical responsibilities collectively for greater hermeneutical sensitivity in their relationships with Indigenous communities as interlocutors and as epistemic beneficiaries of settler colonialism. I follow Campbell's lead in moving beyond blame when

\footnotetext{
${ }^{18}$ Nonetheless, I contend that there are situations in which settler-colonizers are blameworthy for their epistemic laziness or willful White ignorance. On the one hand, because of their power and privilege, settler-colonizers also have the ability to know about Indigenous peoples and histories. On the other hand, new arrivants who are at a disadvantage in understanding the Canadian landscape beyond the hermeneutical norms of White settler society might be less blameworthy.
} 
considering how to rebuild relationships and respond collectively to past and ongoing harms (Campbell 2014, 148). In my account, Campbell's framework of relational remembering provides a starting point. More specifically, the upshot of Campbell's framework of remembering reveals that good remembering renders the link between memory and responsibility as forward-looking. This means that good remembering can capture the significance of the damages done to Indigenous people so as to deepen our understanding of past harms and of how we might respond to them and their legacies (148). An account of activities of good remembering can help address communicative dynamics within institutions and among people of power that delegitimize the past and perpetrate ongoing harms faced by Indigenous communities in Canada.

In the Canadian settler-colonial context, the concept of generational bypassing invokes the belief that there is no longer any highly visible colonization/racism and, thus, there is no need to care about, be accountable to, or take up information that challenges the peaceful nation-building narratives of settlers. In response to this and by way of sketching an account of hermeneutical obligations, I refer briefly to Iris Marion Young's account of the social connection model of responsibility: "Responsibility from social connection says that those who act within unjust structures have a responsibility to try to make them more just (Young 2011, 180). In highlighting how settler-colonizers and many arrivants have denied or ignored relationality, interdependence, and communicative dynamics with Indigenous peoples, my account can be said to deepen and strengthen Young's model of social connection and of the responsibilities that emerge.

In the following section, I suggest a few corrective methodological responses that can help settler-colonizers and arrivants collectively understand settler positionality and 
correct the communicative dynamics that silence, dismiss, and disregard Indigenous voices.

\subsection{Moral Disorientation and Approaching Repair}

In her book Disorientation and Moral Life, Ami Harbin provides a philosophical account of disorientation that she defines as experiences that "involve feeling deeply out of place, unfamiliar, or not at home" (Harbin 2016, 2). According to Harbin, certain types of disorientation can be morally beneficial because certain ways of being disoriented are concurrent with our development as moral agents (21). Though experiences of disorientation are ubiquitous, Harbin details types of disorientation that can cause "individuals to gain new awareness in politically and morally important ways" (66). There are different contexts in which such disorientation can occur. For example, disorientation can result from experiencing the harms of anti-immigrant nationalism or gender-based violence (66). My focus will be on the disorientations that can happen for settler-colonizers and arrivants when they experience themselves as privileged, a kind of disorientation that Harbin refers to as "White ambush" (73). In the following section, I apply Harbin's account of "White ambush" to show that the experiences of White settler society and racialized arrivants who support or are unaware of colonial power and privilege can be shaken in morally and politically important ways.

\subsubsection{The experience and value of disorientation and White ambush in moral life}

Harbin argues that disorientation, or the feeling of being deeply out of place, unfamiliar, or not at home, can be beneficial because it can help develop greater moral agency by making space for gaining awareness of oppressive norms and political complexities that are either outside one's experiences or distorted by one's experiences and interpretive 
resources. For example, she outlines how White people can become aware of their White privilege through the disorientation of White ambush that has them confront their White positionality and its presuppositions, privileges, and consequences. Harbin explains that, for some people, the process of recognizing their White privilege, its significance, and the ways in which it works to veil their own racism and White ignorance can be a very disorienting experience (76). In fact, this realization can be so disorienting that it may feel like an attack or ambush on how one has oriented themselves their whole life. However, Harbin maintains that the "disorientations of White ambush can prompt awareness of contingent racist norms that we are helping to perpetuate" (75). She encourages allowing oneself to feel the disorientating nature of White ambush in order to raise one's consciousness of oppressive norms and political complexity outside of their usual purview. To apply this to the case at hand, the disorienting forces of facing 'White ambush' as a result of heightened awareness of one's own privilege and racism can help explain how White settler society can learn about their historical and contemporary relationship with the Canadian settler-colonial project, their colonial relationships to Indigenous peoples, the complexity of a social landscape that is still structured by oppression and privilege, and their place and role in such structures (78). Importantly, in Harbin's account, these experiences of learning can disorient individuals in a way that triggers their awareness and orients them towards action (78).

I also want to apply the concept of "White ambush" to arrivants who can learn about oppressive norms and political complexity in Canada as it relates to their own social position and experience but who also often struggle to recognize how they may be complicit in perpetuating the marginalization of Indigenous peoples. I believe arrivants 
may need to welcome a 'settler ambush' to disrupt the "mental, emotional, and material habits" (Regan 2010, 27) associated with their settler identity, one that has had them take up pre-existing worldviews and interpretive resources from White settler society. In my experience, well-meaning allies in my own community often fail to see their own privilege and complicity in the ongoing colonization of Canada even though they can recognize this for White settlers-colonizers. As I have argued in Chapter 4, arrivants can also operate in spaces of ignorance/unawareness like that of White settlers by relying on White ignorance to understand Canada. I will end this chapter by returning to the role that arrivants can play in Section 6.4.

\subsubsection{Applying lessons from moral disorientation: doubling back and settler- \\ colonialism}

What I draw from Harbin's work on disorientation and its potential for new awareness and being oriented towards action is that it is exactly what settlers need to lean into and welcome in order to address and acknowledge the hermeneutical power they collectively possess over Indigenous knowers. Recall from Chapter 4, section 4.3, that settlers' hermeneutical power has a very real performative and interactive component: we can silence Indigenous communities in and through the ways we might fail to be reciprocally responsive, open, or trusting of Indigenous voices. As I argued in connection with explaining Medina's version of communicative interactionism in Chapters 1 and 4, epistemic virtues, such as openness, will be imperative for correcting communicative interactions that marginalize, deny, and ignore. Likewise, Campbell's framework for relational remembering of the past and forward-looking responsibilities stress virtues such as being trusting of Indigenous voices when they share their experiences of 
oppression and of centering values such as accuracy, integrity, and responsibility in the way that we remember the past. In addition to these values, leaning into moments of disorientation is vital not only for correcting communicative dynamics via epistemic virtues but for attuning individuals to the "particularities of an unjust moral landscape in ways that allow them to respond well to it in some ways, for some period of time" (Harbin 2016, 31).

When these interactive components are sought out, collectively valued, and repeated, there is a greater chance for collective hermeneutical sensitivities to the interpretive resources Indigenous communities are sharing. As suggested previously, the role of trust is important in relationships and is exhibited in deference to the authority and leadership of Indigenous groups in achieving decolonial goals (such as preventing the extinction of a particular Indigenous language, for example). As Harbin explains, while disorientation can happen spontaneously and take one by surprise, it is also something we can seek out (Harbin 2016,3). One way in which settlers can do this is by what she calls doubling back. According to Harbin, doubling back means "treading the same ground over and over, where that ground is all the time changing, and we regularly confront injustices as they show up in new and (sometimes) unpredictable ways" (142). In doubling back and reminding ourselves of how deeply the settler mindset affects our inability to be hermeneutically sensitive to the world revealed and experienced through Indigenous interpretative resources that have been marginalized and silenced, we can pursue morally beneficial experiences of disorientation that generate openings for continued learning, re-remembering, and re-evaluating "mental, emotional and material 
habits" that position White settler society as innocent and having merely settled/developed land (Regan 2010, 27).

I argue that continued actions of doubling back and leaning into disorientation for settlers are imperative because, as covered in Chapter 2, historical harms of Canada's settler colonialism are ongoing in and through the converging forces of elimination, structured invasion of land. and capitalist modes of resource extraction. These factors continue to structurally and foundationally position White settler society as dominant—a dominance reflected in the institutions, laws, constitution, and rule of law that are now integral to the Canadian state and imposed on Indigenous peoples (as well as other racialized arrivants) (Koggel 2018). For this reason, doubling back is necessary for all settlers collectively, but especially for settler-colonizer legal fictions, such as the Doctrine of Discovery, that are fundamentally centered on gaining sovereignty over Indigenous peoples, their lands, and resources through a structured dispossession of their land and resources, which continue to be applied and to have influence. Moreover, Harbin explains,

"Doubling back" action against injustice is not resolute movement toward a goal, but a constant questioning and challenging of unjust tendencies, and cultivating capacities to hear challenges from others. It is irresolute, precisely because it starts from having destabilized the expectation that one's own judgment is likely to be the best. "Doubling back" is an effort that starts from suspicion about, for example, what parts of colonial relations settlers think of as natural or inevitable. The efforts of settlers to decolonize are "doubling back" actions when they follow the leadership of 
indigenous people, continually challenge colonial habits of thinking, and adjust to new understanding. (Harbin 2016, 142)

In Canada's context of settler-colonial injustices and misremembering, doubling back is necessary for settlers to commit, in the long term, to challenging their "mental, emotional, and material habits" (Regan 2010, 27) that hold settler situatedness in high regard in relation to Indigenous communities. Part of this process of doubling back, as Harbin notes, helps to prevent old paternalistic power dynamics and tendencies "of dominating Indigenous groups, thinking that we know best about how to re-establish First Nations and settler relations, and protecting the resources we have gained through colonialism" (Harbin 2016, 143).

In the section that follows, I develop these insights further by arguing moral deference, as articulated by Laurence Thomas, will give settlers what I call "methodological decentering."

\subsubsection{Moral deference and disorientation as a practice of methodological} decentering for Settler-Colonizers

In "Moral Deference," Laurence Thomas argues that the marginalized are owed moral deference. He defines moral deference as having the appropriate moral attitude when trying to understand the ways in which someone is "downwardly constituted" by experiences of oppression/marginalization (Thomas 1998, 368). The central insight I would like to draw from Thomas is that marginalized people have a specific vantage point to their own experiences that others, who do not share their social identity, cannot access (374). Moral deference is an attitude that does not necessarily entail understanding the experiences of the oppressed/marginalized or even having goodwill towards them; 
rather, it is a moral power that we have to listen to the pain of the oppressed/marginalized with their authorization and by gaining their trust (379). The point of moral deference is not about bearing witness to the pain of the marginalized to see how you have been affected by another's pain. Rather, moral deference is specifically about listening to the stories of the marginalized in such a way that you can bear witness to their moral pain to allow yourself "to be affected in a direct interpersonal way by the injustices of the world" (378).

For settlers who are collectively moving forward to repair, renew, and rebuild relationships with Indigenous communities, another strategy ought to be deferring to the special insights that Indigenous peoples have on how to move forward with healing and how to alleviate Indigenous peoples' marginalization. For this reason, I argue that both deference and disorientation are imperative for Canadian society to effectively approach meaningful and long-term reconciliation and repair within their relationships. This argument is because my account of the nature of willful hermeneutical ignorance for dominantly situated settler-knowers in Canada shows that they will inevitably fail to fully grasp the effects of the structural, foundational, and interpersonal oppression of Indigenous communities in the past and present. As feminist scholar Uma Narayan explains, insiders of an oppressed group are "more likely than the outsider to know the extent to which a form of oppression permeates a society and affects the lives of its victims and of the very subtle forms in which it can operate" $(1988,39)$.

Consequently, I propose methodological decentering, a remedial measure to approach hermeneutical insensitivities and willful ignorance by settlers. This decentering brings together and urges the practice of moral deference and disorientation for settlers in 
their relationship to Indigenous peoples in Canada and requires a good remembering that works in the background to deference and disorientation to remember the history of Canada (and White settler society) as one of settler-colonial harms to Indigenous peoples. As Campbell states, as it is, "Non-Indigenous Canadians have rarely participated in activities of sharing memory that would allow the narratives and embodied practices of First Nations, Inuit, or Métis peoples to have force in re-shaping our experience of pasts that we thus continue to re-live from the colonialist perspective of our forebears" (Campbell 2014, 104). As such, methodological decentering is a practice specifically for dominantly situated knowers to take up as the first step in acknowledging the ignorance that is willfully maintained. The purpose of this corrective measure is to displace the hermeneutical power that dominantly situated knowers have and continue to performatively invoke. It accomplishes this task by requiring processes of disorientation and moral deference from dominantly situated knowers. I will sketch how moral deference along with disorientation informs the practice of methodological decentering.

The practice of methodological decentering incorporates the idea of moral deference in two ways: as with feminist standpoint theory, it recognizes that marginally situated knowers have a specific vantage point to their own experiences that the dominantly situated may never truly understand, and it demands that dominantly situated knowers be appropriately receptive to experiences of the marginalized (as they are revealed by the marginalized) in such a way that acknowledges the injustice of their epistemic exclusion/oppression/marginalization. I argue that these factors of moral deference and the disorientation one feels when learning about oppression are crucial in the decentering process of dominantly situated knowers. The moral deference and 
disorientation involved in methodological decentering enable settler-colonizers to take responsibility in acknowledging and being accountable for addressing how their hermeneutical power is maintained.

Methodological decentering means that good remembering involves acknowledging the structural, foundational, material, and relational power that settlers have at the expense of the material and hermeneutical marginalization of Indigenous communities. Subsequently, methodological decentering urges settler-colonizers to expand their collective interpretive resources and relinquish hermeneutical dominance by leaning into strategies of moral disorientation and moral deference. Methodological decentering allows one remedy for willful hermeneutical ignorance and poor/silencing communicative dynamics when listening and learning from Indigenous peoples' perspectives that challenge their memory, settler presuppositions, and positionality. While I stress methodological decentering for settler-colonizers due to the role of racial hierarchy, White supremacy, and the position of White settlers with respect to Indigenous and racialized people, it is still very applicable for arrivants as a method of challenging the dominant interpretive resources in Canada. In the next and final section, I examine the unique performative and interactive role arrivants have in their capacity to resist hermeneutical gaps and/or become perpetrators of hermeneutical injustice.

\subsection{Resistance and Allyship in Arrivant Communities}

The relational communicative account I have been defending can also highlight the intersectional and pluralistic aspects of Canada's context of differently situated voices with different possibilities for epistemic agency. This is especially true of arrivant communities, who can produce interpretative diversity and the possibility of 
hermeneutical dissidence. Recall that because of such pluralities that exist in a complex social body, Medina takes issue with Fricker's conception of collective interpretive resources and asks, "Is there always such thing"? In most of my analysis thus far, I have made use of Fricker's initial conception of "collective interpretive resources" to spotlight the dominant collective interpretive resources of White settler society, which is often expected of and taken up by arrivants. As noted in Chapter 4, section 4.3, the positionality of arrivants on Turtle Island cannot be treated as a collective monolith, as arrivants form multiple publics that have heterogeneous subgroups with diverse resources. Under the conditions of oppression that they face in Canada (and in their places of origin as well as the broader international community), this heterogeneity is further accentuated and has the potential for diverging from dominant interpretive norms. This potential is primarily because many non-White arrivants do not exclusively live in the White world, so they are required to understand the dominant world as well as the world experienced in the margins.

Communicative interactionism here provides us with a way of looking at how collective interpretive resources are taken up and/or resisted in Canada's diverse arrivant community under the greater system of settler-colonial oppression. Although arrivants are beneficiaries of Canada's settler colonialism, many arrivants are also hermeneutically disadvantaged in a way that is characteristic of their own communities' situatedness in Canada. As marginalized knowers themselves, arrivants are required to use and be aware of dominant collective interpretive resources but will also find gaps in the collective/dominant epistemic resources for making sense of their own marginalized experiences. Consequently, they may have a more acute sensitivity/attunement to 
hermeneutical gaps from experiencing their own inability to speak as well as of the racialization processes they are subjected to by Canadian society (both domestically and internationally) and from experiencing the inability of their interlocutors to listen to them.

In the context of immigrants in the U.S., Medina writes that such experiences can be "fertile soil" for the development of a special sensitivity to insensitivity (Medina 2013, 204). Arrivants can take up insensitive mental, emotional, material, and communicative habits of White settler society due to their assimilating or aligning with the dominant collective resources. Nonetheless, the experience of their own oppression and racialization in Canada does afford an opportunity to go beyond the received dominant view. Arrivants can be better positioned to "recognize its limitations and flaws, and occasionally to develop an alternative viewpoint, a dual consciousness, or even a kaleidoscopic consciousness that can hold and maintain active multiple perspectives simultaneously" in White settler societies (Medina 2013, 74). Though Medina applies these insights to arrivants in the U.S., arrivants in Canada (as with White settlers) can move beyond the dominant testimonial insensitivity that fails to hear Indigenous voices and instead embrace alternative ways of speaking, listening, and holding standpoints to occupy in testimonial exchanges.

In the case at hand of settler/colonial Canada, an example of this development occurred in pockets for the Bengali community in Toronto during the Wet'suwet'en protest of the construction of the Coastal GasLink Pipeline through Wet'suwet'en First Nation territory in British Columbia (BC). During this time, Bengali community organizers, such as Fatin Chowdary, sought to engender Bengali-Wet'suwet'en solidarity (and Bengali-Indigenous solidarity at large) by encouraging the community to reflect on 
Bangladeshis' historical struggle for their land, language, and the ongoing campaign for climate justice and how this could be extending in support for Wet'suwet'en and Indigenous peoples as they challenge and resist structured invasions of Indigenous land. This is a type of epistemic resistance to the Canadian-Bengali mindset that engages in epistemic practices of actively comparing and contrasting experiences and perspectives, and thus creating hermeneutical openness and even "doxastic responsibility" (defined as "the space of reasons") (Medina 2013, 79). This is not to say that an arrivants' potential for hermeneutical sensitivity towards Indigenous interpretive resources is easy or can be carried over to the full range of varying issues and areas of life. I want to note that even when such attempts are made, we should be cautioned that they may not happen without epistemic friction. Medina explains,

The liberatory moves and the hermeneutical tools for emancipation produced by an oppressed group are not always transferable and applicable to the fight against other hermeneutical gaps, against other oppressive limits to intelligibility and other forms of insensitivity; but they constitute resources that are good to have and can prove helpful when encountering oppression and hermeneutical marginalization elsewhere, if only in the sense of being familiar with the predicament of being hermeneutically excluded, of having uninterpretable experiences and problems, and not in the sense of knowing a way out or being able to provide new interpretative tools. (Medina 2013, 74)

As marginalized knowers themselves, arrivants are required to use and be aware of dominant collective interpretive resources but will also find gaps in the collective/dominant epistemic resources for making sense of their own marginalized 
experiences. As discussed in Chapter 2 these are insights central to feminist standpoint theory. This process can provide arrivants with a "loose and collective experiential advantage of the oppressed over the privileged" that offers them the capacity 1) to see alternatives to the collective interpretive resources that have already been constituted by White settler society; 2) to have a pronounced sensitivity to the experiences of Indigenous communities; and 3) to subsequently offer resistance to hermeneutical gaps and fight epistemic injustice (74). The main message is that this process is possible and necessary for all settlers. However, many racialized arrivant communities may have a more pronounced capacity to do so, regardless of their less direct interdependence with Indigenous communities, than settler-colonizers. Honing this insight, as well as prioritizing ways of understanding their position and relationship to Indigenous peoples through practices such as methodological decentering can help us establish new interpretative tools 


\section{Chapter 7: Conclusion}

My thesis sets out to investigate and build on Koggel's insight that Canada's dominant collective interpretive resources reflect "attempts to denigrate, dismiss, and erase Indigenous laws, practices, languages and traditions," which have caused lasting hermeneutical gaps in the dominant collective interpretive resources of Canadian society (Koggel 2019, 1). In each chapter, I build on Koggel's insights to further argue that willful hermeneutical ignorance, when merged with Medina's communicative interactionism, presents us with the most appropriate entry point to analyze how positionality and relationality of settler-colonizers and arrivant groups, as they have emerged from within Canada's past and present settler-colonialism, are influencing factors in instigating and sustaining a distinct type of willful hermeneutical ignorance.

Many things are revealed in my investigations. For example, the nature of epistemic injustice faced by Indigenous communities in 'Canada' goes beyond Fricker's original conception of hermeneutical injustice. I have shown that what is characteristic of hermeneutical gaps in Canadian society is that regardless of the status of intelligibility, settlers have continued to preemptively dismiss or refuse and remain ignorant of Indigenous interpretive resources, thereby wronging Indigenous people as knowers or transmitters of knowledge. I have shown how this stance has required an active ignorance on the part of the settlers to maintain their hermeneutical dominance.

Fricker asserts that those hermeneutical injustices take place when and because "a collective hermeneutical gap prevents members of a group from making sense of an experience that is in their interest to render intelligible" (Fricker 2007, 7). I have shown that in the case of settler-Indigenous relations in Canada, what is meant by preventing the 
"making sense of an experience" is present in their relationship with settlers, who have ignored, dismissed, silenced, or otherwise marginalized Indigenous interpretive resources. Subsequently, I have argued that hermeneutical gaps, in this case, are better understood through the context of communicative interactions that silence, dismiss, and disregard Indigenous voices. I conclude that many of these communicative attempts reflect early settler-colonial relationships of power and oppression that have evolved to help sustain a form of epistemic injustice towards Indigenous communities in Canada. However, as Medina writes, "through repeated attempts to communicate with ourselves and with those around us about experiences that have been obscured and hermeneutically marginalized, we can expand our hermeneutical sensibilities and eventually add to the hermeneutical resources of our group through contributions that could also spread to other groups, with new interpretative tools acquiring progressively wider circulation" (Medina 2013, 98). In my account, such communicative attempts would also need to be practiced with the methods outlined in Chapter 6 .

The thesis was motivated in large part to understand the artworks of Scott Benesiinaabandan (Anishinabe), Nadia Myers (Kitigan Zibi, Anishnaabeg First Nation), and Mary Ann Barkhouse (Nimpkish band, Kwakiutl First Nation). I was exposed to their artworks in a gallery setting where I was in the position of being a public educator relaying the meanings of each work to an audience. While I learned a great deal from each artist's work and the messages they were conveying about their respective cultures, political issues, and histories of past and ongoing harms that their communities have faced, I also realized that after 18 years of living in Canada, I knew very little about Indigenous people and history. This realization was the beginning of my understanding of 
who gets to tell and shape the collective interpretive resources that we rely on to understand Canadian history and, in turn, what interpretative resources have shaped and will shape the relationship between Indigenous people and settler Canadians. I believe that only by doing so, can settlers turn to properly understanding and addressing issues that are born from a willful dismissal of Indigenous interpretive resources. Such issues span all facets of Indigenous life and wellbeing in Canadian society, such as Indigenous land rights, responding to recent demands for an inquiry into the Sixties and Millennial scoops and the Inquiry into Missing and Murdered Indigenous Women and Girls ${ }^{19}$, demands to suspend the Catholic church's status as a charitable organization as a consequence of their violations and as a means to obtain undisclosed documents related to residential schools and promised financial compensation to survivors ${ }^{20}$, the continued calls to confront and investigate systemic racism in the RCMP ${ }^{21}$, and calls for a nationwide ban on birth alerts ${ }^{22}$ (which impact Indigenous communities disproportionately), just to name a few. As Koggel states, "foundational and structural injustices in settler nations are at bottom epistemic injustices, ones that reach to the foundations and structures of a colonizing/settler nation and have implications for accounts of agency, participation, and self-determination" (Koggel 2019, 16).

\footnotetext{
19 60s Scoop Legacy of Canada group is calling for a federal inquiry: https://www.cbc.ca/news/canada/manitoba/sixties-scoop-survivors-call-for-national-inquiry-1.6127154 ${ }^{20}$ David Thomson starts a petition demanding that the Catholic Church provide full documentation on residential schools and unmarked graves: https://www.cbc.ca/amp/1.6130064

${ }^{21} \mathrm{https}$ ://toronto.citynews.ca/2021/05/19/relation-between-indigenous-and-rcmp-founded-on-oppressionas-strained-as-ever-activist/

${ }^{22}$ The executive director of the Mi'kmaq Native Friendship Centre states that birth alerts discourage Indigenous women and families from accessing medical care and supports:

https://www.cbc.ca/news/canada/nova-scotia/birth-alerts-mothers-babies-child-welfare-indigenous-women1.5904676
} 


\section{Bibliography}

Allen, Jane. 2021. "Winnipeg Catholic Priest Accuses Residential School Survivors of Lying about Abuse for Money." CBC News, July 29, 2021.

https://www.cbc.ca/news/canada/manitoba/rheal-forest-residential-schools-1.6121886.

Angus Reid Institute. 2018. "Truths of Reconciliation: Canadians Are Deeply Divided on How Best to Address Indigenous Issues.” June 6, 2018. Accessed 20 August 2021. http://angusreid.org/wp-content/uploads/2018/06/2018.04.23 indigenous fullreport.pdf.

Asch, Michael, ed. 1997. Aboriginal and Treaty Rights in Canada: Essays on Law, Equity, and Respect for Difference. Vancouver: UBC Press.

Braun, Lundy. 2015. "Race, Ethnicity, and Lung Function: A Brief History." Can J Resp Ther 51, no. 4 (Fall 2015): 99-101. http://www.ncbi.nlm.nih.gov/pubmed/26566381.

Brownmiller, Susan, and Dolores Alexander. 1992. "How We Got Here From Carmita Wood to Anita Hill." Ms. Magazine, 1992. http://www.nfwfwf.org/wpcontent/uploads/2018/02/BROWNMILLER-ALEXANDER-MS-MAG-1992.pdf.

Byrd, Jodi A. 2011. The Transit of Empire. NED-New edition. University of Minnesota Press. http://www.jstor.org.proxy.library.carleton.ca/stable/10.5749/j.ctttv97j.

Campbell, Sue. 2014. Our Faithfulness to the Past: The Ethics and Politics of Memory. Edited by Christine M. Koggel and Rockney Jacobsen. Oxford University Press.

Chapman, Elizabeth N., Anna Kaatz, and Molly Carnes. 2013. "Physicians and Implicit Bias: How Doctors May Unwittingly Perpetuate Health Care Disparities." Journal of General Internal Medicine 28 (11): 1504-10. https://doi.org/10.1007/s11606-013-2441-1.

Coulthard, Glen Sean. 2014. Red Skin, White Masks: Rejecting the Colonial Politics of Recognition. Indigenous Americas. Minneapolis: University of Minnesota Press.

Du Bois, W. E. B., and Brent Hayes Edwards. 2007. The Souls of Black Folk. Oxford World's Classics. Oxford [England]; New York: Oxford University Press.

Environics Institute for Survey Research. 2016. "Canadian Public Opinion on Aboriginal Peoples. Final Report.” https://www.environicsinstitute.org/docs/default-source/projectdocuments/public-opinion-about-aboriginal-issues-in-canada-2016/finalreport.pdf?sfvrsn $=30587$ aca 2 . 
Filice, Michelle. n.d. "Haldimand Proclamation." In The Canadian Encyclopedia. Historica Canada. Accessed 20 August 2021. https://www.thecanadianencyclopedia.ca/en/article/haldimand-proclamation.

Forester, Brett. 2021. "OPP Spent More than \$16M Policing 1492 Land Back Lane: Records." March 30, 2021. APTN, sec. National News. https://www.aptnnews.ca/nationalnews/opp-spent-more-than-16m-policing-1492-land-back-lanerecords/?fbclid=IwAR2upZ8vXHsiOhgNdDM t4D6p1rE 8DKzkZa1XlAiYDUcz2Syg6 $\underline{17 \mathrm{Vcscz} 8}$.

Fricker, Miranda. 2007. Epistemic Injustice: Power and the Ethics of Knowing. Oxford University Press. https://doi.org/10.1093/acprof:oso/9780198237907.001.0001.

Harbin, Ami. 2016. Disorientation and Moral Life. Studies in Feminist Philosophy. New York: Oxford University Press.

Hoagland, Sarah. 2007. "Denying Relationality: Epistemology and Ethics and Ignorance." In Race and Epistemologies of Ignorance, edited by Shannon Sullivan and Nancy Tuana, 95-118. SUNY Series, Philosophy and Race. Albany: State University of New York Press.

Koggel, Christine M. 2014. "Relational Remembering and Oppression." Hypatia 29 (2): 493 508. https://doi.org/10.1111/hypa.12079.

. 2018. "Epistemic Injustice in a Settler Nation: Canada's History of Erasing, Silencing, Marginalizing." Journal of Global Ethics 14 (2): 240-51. https://doi.org/10.1080/17449626.2018.1506996.

_ 2019. "Agency, Participation, and Self-Determination for Indigenous Peoples in Canada: Foundational, Structural, and Epistemic Injustices." Éthique Et Économique 17 (1).

MacDonald, David. 2020. "Paved with Comfortable Intentions: Moving beyond Liberal Multiculturalism and Civic Rights Frames on the Road to Transformative Reconciliation." In Pathways of Reconciliation: Indigenous and Settler Approaches to Implementing the TRC's Calls to Action, edited by Aimée Craft and Paulette Regan, 334. Perceptions on Truth and Reconciliation 2. Winnipeg, Manitoba: University of Manitoba Press.

Medina, José. 2012. "Hermeneutical Injustice and Polyphonic Contextualism: Social Silences and Shared Hermeneutical Responsibilities." Social Epistemology 26, no. 2 (April 2012): 201-20. https://doi.org/10.1080/02691728.2011.652214. 
- 2013. The Epistemology of Resistance: Gender and Racial Oppression, Epistemic Injustice, and Resistant Imaginations. Studies in Feminist Philosophy. Oxford; New York: Oxford University Press.

Mills, Charles W. 2007. "White Ignorance." In Race and Epistemologies of Ignorance, edited by Shannon Sullivan and Nancy Tuana, 11-38. SUNY Series, Philosophy and Race. Albany: State University of New York Press.

—. 2011. The Racial Contract. Ithaca, NY: Cornell Univ. Press.

Narayan, Uma. 1988. "Working Together across Difference: Some Considerations on Emotions and Political Practice." Hypatia 3 (2): 31-47.

Nungak, Zebedee. 2017. Wrestling with Colonialism on Steroids: Quebec Inuit Fight for Their Homeland. Dossier Québec Series. Montréal: Véhicule Press.

Orenstein, David. 2013. “Spirometry: A Built-in ‘Correction' for Race?” News From Brown (blog), June 3, 2013. https://news.brown.edu/articles/2013/06/spirometers.

Ozguc, Umut. 2011. "Remaking Canadian Identity: A Critical Analysis of Canada's Human Security Discourse." Journal of Human Security 7 (3): 37-59. https://doi.org/10.3316/JHS0703037.

Patterson, Brent. 2020. "1492 Land Back Lane Highlights Need to Address Land Theft Instead of Criminalizing Land Defenders.” The Canada Files, 11 October 2020. https://www.thecanadafiles.com/articles/ddfew.

Petz, Sarah. 2021. "New Manitoba Indigenous Minister Says Residential School System Believed 'They Were Doing the Right Thing."' CBC News, July15, 2021. https://www.cbc.ca/news/canada/manitoba/alan-lagimodiere-comments-residentialschools-1.6104189.

Pohlhaus, Gaile. 2012. "Relational Knowing and Epistemic Injustice: Toward a Theory of Willful Hermeneutical Ignorance." Hypatia 27 (4): 715-35. https://doi.org/10.1111/j.1527-2001.2011.01222.x.

Pope Alexander VI. 1493. "Inter Caetera: Division of the Undiscovered World between Spain and Portugal." https://www.papalencyclicals.net/Alex06/alex06inter.htm.

Razack, Sherene, ed. 2002. Race, Space, and the Law: Unmapping a White settler society. Toronto: Between the Lines. 
—2004. Dark Threats and White Knights: The Somalia Affair, Peacekeeping, and the New Imperialism. Toronto; Buffalo: University of Toronto Press.

Regan, Paulette. 2010. Unsettling the Settler within: Indian Residential Schools, Truth Telling, and Reconciliation in Canada. Vancouver: UBC Press.

Saul, John Ralston. 2008. A Fair Country: Telling Truths about Canada. Toronto: Viking Canada.

Simpson, Audra. 2014. Mohawk Interruptus: Political Life across the Borders of Settler States. Durham: Duke University Press.

Stauffer, Jill. 2015. Ethical Loneliness: The Injustice of Not Being Heard. New York: Columbia University Press.

Thomas, Laurence. 1993. "Moral Deference." Philosophical Forum 24 (1-3): 232-50.

Truth and Reconciliation Commission of Canada, ed. 2015a. Canada's Residential Schools: The Final Report of the Truth and Reconciliation Commission of Canada. McGillQueen's Native and Northern Series 80, $<82-86>$. Montreal: McGill-Queen's University Press.

- 2015b. Honouring the Truth, Reconciling for the Future: Summary of the Final Report of the Truth and Reconciliation Commission of Canada.

Tsosie, Rebecca. 2017. "Indigenous Peoples, Anthropology, and the Legacy of Epistemic Injustice." In The Routledge Handbook of Epistemic Injustice, edited by Ian James Kidd, José Medina, and Gaile Pohlhaus, 1st ed., 356-69. 1 [edition]. | New York: Routledge. https://doi.org/10.4324/9781315212043.

Unequal Treatment: Confronting Racial and Ethnic Disparities in Health Care (with CD). 2003. Washington, D.C.: National Academies Press. https://doi.org/10.17226/12875.

Unger, Danton. 2021. “'You Can't Be Out Here Defending Residential Schools': Opposition Leader Calls out Manitoba's New Indigenous Relations Minister." CTV News, 15 July 2021. https://winnipeg.ctvnews.ca/you-can-t-be-out-here-defending-residential-schoolsopposition-leader-calls-out-manitoba-s-new-indigenous-relations-minister-1.5510619.

Vowel, Chelsea. 2020. "Settling on a Name: Names for Non-Indigenous Canadians." Apihtawikosisân Law Language Culture (blog). 28 February 2020. https://apihtawikosisan.com/2020/02/settling-on-a-name-names-for-non-indigenouscanadians/. 
Wagner, Eric. 2006. "The Peaceable Kingdom? The National Myth of Canadian Peacekeeping and the Cold War." Canadian Military Journal 7 (4): 45-54.

Wolfe, Patrick. 1999. Settler Colonialism and the Transformation of Anthropology: The Politics and Poetics of an Ethnographic Event. Writing Past Colonialism Series. London; New York: Cassell.

Young, Iris Marion. 2011. Responsibility for Justice. Oxford University Press. https://doi.org/10.1093/acprof:oso/9780195392388.001.0001. 